\title{
El trienio negro: Valencia, 1389-1391. Turbulencias coetáneas al asalto de la judería ${ }^{1}$
}

\author{
The Dark Trienium: Valencia, 1389-1391. Unrest coinciding with an assault \\ on the Jewish district
}

\author{
Rafael NARBOnA VizCAÍNO \\ Universitat de València \\ rafael.narbona@uv.es
}

\begin{abstract}
RESUMEN
Estudio de base documental sobre el auge del antijudaísmo desde 1371 y el asalto a la judería de Valencia en julio de 1391, al poco tiempo de su ampliación. Sitúa el hecho en el contexto de las tensiones políticas en la Corona de Aragón y en la ciudad, donde se enfrentaban sendos bandos: actuaciones entre 1375 y 1392 del inquisidor Nicolau Eimeric (Directorium inquisitorum) contra herejes y su condena de obras de Ramon Llull. Cortes de 1388-1389. Guerras en el ámbito pirenaico en 1390. Políticas de abastecimiento y defensa de la ciudad de Valencia y oposición de villas y nobles del reino al municipio de la capital, que arma una milicia montada en mayo de 1391. Represión de maleantes y medidas de pacificación inmediatamente después del asalto a la judería.
\end{abstract}

Palabras clave: Valencia, ciudad y municipio, abastecimiento y milicia. Siglo XIV. Valencia, judíos y judería, asalto de 1391. Corona de Aragón. Cortes de 1388-89. Pedro IV de Aragón el Ceremonioso. Juan I de Aragón. Nicolau Eimeric. Ramon Llull.

\begin{abstract}
This document-based study examines the rise of anti-Semitism beginning in 1371 and the assault on the Jewish district of Valencia in July 1391, shortly after its extension. It situates the violence in the context of political tensions in the Crown of Aragon and in the city of Valencia, where different factions clashed: the actions of the Inquisitor Nicolau Eimerich (Directorium inquisitorum) against heretics and his condemnation of the work of Ramon Llull; the Cortes of 1388-1389; wars in the Pyrenees in 1390; the politics of the city of Valencia's supply and defence and the kingdom's towns' and nobles' opposition to the capital's municipality, which armed a mounted militia in May 1391; the repression of delinquents and means of immediate pacification after the assault on the Jewish district.
\end{abstract}

Key words: Valencia, city and municipality, supply and militia. Fifteenth century. Valencia, Jews and Jewish district, assault of 1391. Crown of Aragon. Cortes of 1388-89. Peter IV of Aragon "the ceremonious". Juan I of Aragon. Nicolau Eimerich. Ramon Llull.

Sumario: Introducción. 1. El saqueo de la judería de Valencia. 2. La creciente hostilidad hacia la judería. 3. Las Cortes de 1388-1389. 4. La monarquía y los herejes. 5. Amenazas de guerra y conflictividad interna. 6. El choque entre la ciudad y el reino. 7. La milicia montada y el orden público. 8. ¿Preguntas sin respuesta?. 9. Conclusión.

${ }^{1}$ Este trabajo es resultado del proyecto de investigación "Redes de sociabilidad judeoconversa y actuación inquisitorial en la Corona de Aragón en el siglo XV", del Ministerio de Educación y Cultura, HAR2008-02650. 


\section{INTRODUCCIÓN}

La historiografía ha asumido que al menos desde 1375 los reinos peninsulares demostraron indicios fehacientes de una creciente aversión y sentimiento de rechazo hacia los judíos. Esta situación general expresaba además un significativo cambio de rumbo en la actitud de algunos cristianos, que introducido por Ferrán Martínez, arcediano de Écija, pretendía no ya humillar sino extinguir las aljamas de Castilla, llamando sin tapujos en sus predicaciones para lograr la conversión con métodos violentos, y bajo declarada amenaza de muerte, si los hebreos perseveraban en $\mathrm{su} \mathrm{fe}^{2}$. La incidencia de las pestes, la Guerra de los Dos Pedros, el fallecimiento de Juan I de Castilla en 1390 y la administración del reino bajo una regencia dividida facilitaron las revueltas, aunque como señaló Benzion Netanyahu aquella nefasta coyuntura no desencadenó los asaltos de las juderías, porque el común detonante fue la continua proximidad a la monarquía y el progreso social de aquella minoría, fenómenos de larga tradición que engendraron una espiral de inquinas y difamaciones desde algunos púlpitos, cuando el grupo ya estaba estigmatizado por los más antiguos textos eclesiásticos. No obstante, $\mathrm{y}$ a pesar de la coyuntura negativa, el asalto se produjo en un momento preciso y no en otro. Los furibundos sermones de Martínez provocaron el ataque a algunos templos hebreos en Andalucía durante 1388 y, tras la muerte del arzobispo sevillano, su nombramiento como provisor de la archidiócesis le dio pie para ordenar el 8 de diciembre de 1390 la destrucción de las sinagogas. Con éstas y otras soflamas, que señalaban a los hebreos como génesis de todos los males padecidos y aún venideros, lograba enardecer y conseguía la adhesión del populacho, mientras las enemistades entre la nobleza sevillana, dividida por la sustitución del alguacil y del adelantado, aumentaron el malestar y los riesgos de violencias en la ciudad, los cuales culminaron con una explosión antijudía de calibre hasta entonces desconocido ${ }^{3}$.

El 4 de junio de 1391 se produjo el asalto de la judería sevillana, iniciándose allí un reguero incendiario de agresiones, robos y muertes, propagado en los días posteriores por Andalucía y Castilla. La difusión de la noticia desató una cadena consecutiva de pogromos, cumpliendo la pauta allí establecida, de modo que los sucesivos asaltos parecían indicar incluso el desplazamiento de una comitiva, que aplicaba a su paso las directrices y enunciados del arcediano o, al menos, que participaba en sus mismos ideales ${ }^{4}$.

2 José María Monsalvo Antón, Teoría y evolución de un conflicto social. El antisemitismo en la Corona de Castilla en la Baja Edad Media, Madrid, Siglo XXI, 1985, cap. VIII, "1375-1391. Escalada hacia un clímax", pp. 345-263.

${ }^{3}$ Benzion Netanyahu, Los orígenes de la Inquisición en la España del siglo XV, Barcelona, Crítica, 1999, cap. II, pp. 112-149. La "anormalidad" del asalto de 1391 acababa por descontextualizar para siempre la coexistencia, incluso violenta, de las tres confesionalidades, pues ponía fin a la aljama y con ello a los cíclicos ataques que en determinadas fechas del calendario se perpetraban contra los judíos. Sobre la transformación de la violencia ritual contra la minoría en violencia cataclísmica entre 1348 y 1391 cfr. David Niremberg, Comunidades de violencia. La persecución de las minorías en la Edad Media, Barcelona, Península, 2001, en especial el epílogo de la obra, y pp. 352-353.

4 El asalto de la judería de Barcelona tuvo como protagonistas a cincuenta castellanos llegados vía marítima desde Valencia y, al menos, diez de ellos fueron reconocidos también como autores del asalto de Sevilla. No obstante, estos agitadores contaron con el respaldo de gentes que se enrolaban en la armada, de vecinos, e incluso de los sermones antijudíos de mosén Pons de Sala, cfr. F. Fita, "Estrago 
El contagio del movimiento superó rápidamente las fronteras. Jaume Riera ha subrayado la tensión social preexistente en los reinos de la Corona de Aragón, tal y como refleja la documentación de la cancillería real: Alcañiz, Girona, o la misma Valencia, demostraron aquella maligna animosidad antes de aquella fecha ${ }^{5}$. De hecho, Juan I de Aragón comunicó por escrito al infante Martín, el 3 de julio de 1391, la noticia de lo acaecido en Sevilla un mes atrás, señalando los peligros derivados del consentir el mal hablar de la población así como las injurias contra los judíos en el reino de Valencia, advirtiendo que era necesario estar prevenido para evitar escándalos y daños irreparables ${ }^{6}$. Todas las precauciones fueron pocas, porque la primera judería atacada en la Corona de Aragón fue la de Valencia, ocurrida el 9 de julio de 1391, apenas una semana después de la carta remitida por el rey a su hermano, y treinta y cinco días posterior al asalto de Sevilla. A aquel acontecimiento la historiografía ha prestado atención desde antiguo, pero todos los autores han presentado los asaltos desvinculados de las circunstancias que en aquel momento padecía la ciudad de Valencia y, con ello, quizás involuntariamente, presentaron el hecho como algo inaudito e incomprensible, achacando las responsabilidades a las arraigadas actividades usurarias de los hebreos y a los vientos xenófobos procedentes de Andalucía y de Castilla lo que -sin minorar su importancia- no puede esconder la preexistencia de un ambiente coetáneo muy conflictivo, que habría de desencadenar la violencia cataclísmica.

\section{EL SAQUEO DE LA JUDERÍA DE VALENCIA}

El desarrollo de los acontecimientos durante el asalto, alargado desde el mediodía hasta finalizar la noche del 9 de julio de 1391, está detallado a partir del relato exculpatorio de los jurados en el momento inmediatamente posterior a los hechos, e incluso contemplaba el atestado notarial de un portentoso milagro, pues se comprobó que las vacías crismeras de las iglesias se habían colmado de forma sobrenatural para permitir la masiva conversión? ${ }^{7}$ En cualquier caso, el resultado fue el completo saqueo

de las juderías catalanas en 1391. Relación contemporánea", BRAH 16 (1890) pp. 433-444 y 440. Sobre la intermediación de personas forasteras, que mediante proclamas preconizaron la destrucción de la aljama de Xàtiva, entre la noche del 10 de julio y el alba del día siguiente, inmediatamente después de tener noticia de la conversión de los judíos de Alzira, cfr. José Hinojosa Montalvo, La judería de Xàtiva, Xàtiva, Ajuntament, 1998, vol. 1, doc. 40, p. 41. Los jurados de Morvedre notificaron al rey que gentes de Valencia se habían desplazado para asaltar su judería, cfr. Archivo Municipal de Valencia, en adelante AMV, Letres misives g3-5, fol. 29 (22 julio 1391).

5 La noticia de Alcañiz data de 7 de diciembre de 1388; la de Girona de 26 de mayo de 1390; y la de Valencia de 3 de noviembre de 1390. Esta última ordenaba a los Jurados que no permitiesen maltratos, amenazas o daños contra los judíos porque el cerramiento de la judería en el barrio de la Exerea exasperaba a los vecinos cristianos, cfr. Jaume Riera i Sans, "Los tumultos contra las juderías de la Corona de Aragón en 1391”, Cuadernos de Historia 8 (1977) p. 217.

6 Jaume Riera i Sans, "Los tumultos contra las juderías...", p. 218. También Fidel Fita, "Estrago de las juderías catalanas...”, pp. 432-445.

${ }^{7}$ La noticia de que el asalto había provocado la milagrosa conversión de los judíos en Valencia, así como en Orihuela, Murcia, Castellón, en toda la Plana, y en otras villas, aparece en la correspondencia remitida por los jurados de Valencia a distintas instancias para dar a conocer los pormenores del ataque, 
de la aljama, unos doscientos treinta hebreos asesinados y una docena de cristianos muertos $^{8}$. Al día siguiente, lunes, se produjo la conversión de los judíos de Alzira, de manera que la nueva desencadenó esa misma noche el asalto a la judería de Xàtiva y, siguiendo idéntica pauta, lo mismo ocurrió en Gandia, Llíria y Cullera antes del día catorce $^{9}$. La incendiaria cadena continuó extendiéndose, el dos de agosto se producía el asalto en Ciutat de Mallorques, el cinco en Barcelona, y durante los siguientes diez días del mes se propagaba en las ciudades catalanas, llegando hasta Perpiñán el 17 agosto, casi siempre acompañados de disturbios y revueltas populares de distinta índole reivindicativa. El 3 de septiembre Juan I recomendaba al infante Martín, antes de que llegase a Teruel, que impidiera a sus acompañantes difundir el sentimiento de animadversión y los ataques contra aquella aljama con el fin de preservar Aragón de los pogromos ${ }^{10}$.

¿Cuáles fueron las circunstancias que convirtieron a Valencia en la primera caja de resonancia de aquellas tremendas acciones antijudías comenzadas en Castilla? Independientemente de la proximidad geográfica, de las intensas relaciones comerciales y del fluido tráfico de personas entre Castilla y la Corona de Aragón a través del reino de Valencia, se han planteado algunas situaciones que propiciaron el rápido efecto de contaminación y el consecuente éxito del discurso inspirado en el lema "conversión o muerte". Al menos desde el mes de junio las gentes que deseaban enrolarse en la armada que el infante Martín organizaba para partir hacia Sicilia habían comenzado a concentrarse en Valencia, y en especial en torno a la Plaza de la Figuera, donde se asentó la tabla de acordar. Fueron éstos los que se dejaron arrastrar por un nutrido grupo de jóvenes que formando una pequeña comitiva, enarbolando un pendón cru-

cfr. Josef Teixidor, Antigüedades de Valencia, edición del manuscrito de 1767 por Roque Chabás, Valencia, Imprenta de Francisco Vives Mora, 1895, vol. 2, pp. 161-166, donde se transcriben total o fragmentariamente las cartas remitidas desde Valencia el 14, 17, 20, 22, 26 y 28 de julio de 1391.

8 Roque Chabás, "El robo de la judería en 9 de julio de 1391", El Archivo 5 (1891) pp. 37-46. En el mismo volumen se encuentra la nota de Francisco Danvila y Collado documentando el número de muertos, cfr. pp. 235-240. También cfr. Francisco Danvila y Collado, "El robo de la judería de Valencia en 1391. Apuntes históricos", $B R A H 8$ (1886), doc. 236, p. 392, quien realiza una exhaustiva, minuciosa y analítica revisión de las fuentes municipales en torno a los prolegómenos, desarrollo, castigo o perdón por los hechos del asalto.

9 José Hinojosa Montalvo, La judería de Xàtiva..., pp. 39-41. Sobre el perdón otorgado por Juan I a los vecinos de la villa de Alzira, hecha la excepción de los treinta y dos detallados en el documento, reconocidos como cabezas de familia, vecinos domiciliados y asiduos a las reuniones del consell, así como del pago de los ochocientos florines para obtener el perdón cfr. Roque Chabás, "Sección de documentos", El Archivo 2 (1887-1888) doc. 52, pp. 392-396. Más tarde la nómina de los implicados ascendió hasta treinta y ocho pero, en cualquier caso, todos los responsables del asalto eran destacados miembros de la oligarquía local, perfectamente identificados como promotores de la agresión, que no sólo habían gestionado el poder en Alzira sino que eran los principales competidores de los judíos por controlar el mercado local del crédito. Tras la intercesión de algunos cortesanos de Juan I el grupo logró la remisión general y absoluta de su posible culpabilidad el 18 de abril de 1392, a cambio la villa ofreció tres mil florines para la expedición real que partiría hacia Cerdeña, cfr. Antoni Furió, "Diners i crèdit. Els jueus d'Alzira en la segona meitat del segle XIV", Revista d'Història Medieval 4 (1993) pp. 156-158.

${ }^{10}$ Jaume Riera, "Los tumultos ...", pp. 224-225. Sobre la participación de algunos escuderos de la casa del infante Martín en el asalto de Valencia, cfr. la constatación realizada por los jurados de Valencia en la carta de 2 de septiembre de 1391 dirigida a Jaume d'Aragó, obispo de Valencia (1369-1396) y cardenal de Santa Sabina (desde 1388), cfr. AMV, Letres misives g3-5, fol. 51. 
zado y varios crucifijos realizados con cañas, amenazaron a los judíos con el aviso de la inminente llegada del "arcepreste de Sibilia" o "artiaqua de Castella". El rumor de que algunos de los alborotadores habían sido maltratados o muertos por los hebreos favoreció la tumultuosa concurrencia de la masa popular, a la que se unieron castellanos, gentes de pobre condición y vagabundos que rondaban por el mercado. Ese fermento social de inmigrantes, concentrado en una ciudad portuaria, era protagonista habitual de las alteraciones de orden público y caldo de cultivo especialmente fértil para la recepción de las violentas ideas xenófobas, con o sin formas ritualizadas ${ }^{11}$. Sin embargo, en el asalto también participaron vecinos de los aledaños al barrio, e incluso hombres de paraje, miembros de la Orden de Montesa, frailes mendicantes, escuderos de reconocidos linajes y notables ciudadanos. La descripción de los hechos por parte de los jurados en la carta del 14 de julio de 1391, dirigida a Ramon Soler y a Pere Marrades, sus emisarios en la corte de Juan I, transmitían la sospecha de que los jóvenes que desencadenaron la chispa del asalto habían sido azuzados por terceras personas, alguna forastera, lo que parecía presumir entonces que otros de sus promotores eran vecinos reconocibles:

"En veritat està que l l fet hac començament per minyons, qui vengueren de la partida del mercat amb un penonet croat e amb alcunes creus de canyes, volen dir alguns que aquests fadrins, asinestrats o induïts foren per alguns, d'açò bé que hajam algú alié, però lo senyor duc (el infante Martín) ne nosaltres (los jurados) no sabem, ne sentim encara tant que digne sia de relació, majorment per no difamar algú de tort"'12.

En esa carta se notificaba no sólo el asalto de la judería el 9 de julio sino también el intento frustrado de asalto de la morería el día posterior, 10 de julio. En ella se hacía constar que entonces ya se había prendido a una decena de hombres de paraje y a setenta u ochenta del pueblo, incluido al menos un fraile, todos ellos responsabilizados de los disturbios ${ }^{13}$. En efecto, los mismos asaltantes de la judería se dirigieron al día siguiente a la morería con idéntico propósito, aunque la contundente acción del

11 Francisco Danvila presentaba a la Valencia del momento bajo el paradigma de la Gomorra medieval, dada la perspectiva de estudio de un historiador conservador de principios del siglo XX, si bien las realidades que describe coinciden con las de una urbe en ebullición y en efervescente crecimiento a finales del Trescientos, la cual en el siglo anterior había sido un confín fronterizo y que en siglo posterior alcanzaría su época de plenitud como metrópoli. Sobre la criminalidad y la delincuencia coetánea cfr. Rafael Narbona Vizcaíno, Pueblo, poder y sexo. Valencia medieval, 1306-1420, Valencia, Diputación Provincial, 1992, pp. 54-64.

12 Jaume Riera i Sans, "Estrangers participans als avalots contra les jueries de la Corona d'Aragó el 1391", AEM 10 (1980) pp. 577-583. La misma noche del 9 de julio el infante Martín daba cuenta de los acontecimientos a su hermano, Juan I, indicando que el alboroto se prolongó desde mediodía hasta cuatro horas después de la puesta del sol, el cual en el momento en que redactaba el comunicado todavía no había concluido, cfr. del mismo autor "Los tumultos contra las juderías ...", pp. 220-221. El relato de los hechos, recogido en las actas del consell, y transmitido por los jurados a Juan I en varias cartas, han sido publicado por Agustín Rubio Vela, en Epistolari de la València medieval I, València, Institut de Filologia Valenciana, 1985, doc. 103 (9 julio 1391) pp. 269-271 y doc. 104 (17 julio 1391) pp. 271275. El documento citado está transcrito en Josef Teixidor, Antiguedades de Valencia, pp. 161-62, y el original se encuentra en AMV, Letres Misives g3-5 fol. 21 (14 julio 1391).

${ }^{13}$ Sobre la heterogénea participación de gentes notables cfr. Francisco Danvilla y Collado, "El robo de la judería ...”, p. 373. Sobre la carta AMV, Letres Misives g3-5 fol. 20v-22v (14 julio 1391). 
infante, acompañado de una tropa de caballería y de infantería, contuvo a la turba con el expeditivo ajusticiamiento in situ de uno de los incontrolados, según aclaraba también otra carta remitida por Martín a su esposa María de Luna el 20 de julio de $1391^{14}$.

A pesar de la heterogénea participación social en el asalto, convendría recordar que los procedimientos iniciados contra los culpables se alargaron por distintas causas, tal y como señaló Francisco Danvila. Entre éstas cabría subrayar las amenazas que profirieron contra los posibles querellantes algunos magnates o sus familiares, así como la dilatación de los procesos que se habían instado, mediante el envío de cartas privadas al monarca o a los consejeros de su corte, con el propósito de impedir las actuaciones jurisdiccionales, bien del justicia bien del gobernador, las cuales terminaron por paralizar las diligencias e incluso que el propio Juan I se reservara la competencia exclusiva sobre el asunto, sin que apenas se alcanzasen resultados penales en la conclusión del castigo ${ }^{15}$. Los propios jurados reconocían que algunos destacados miembros de la Orden de Montesa y de las órdenes mendicantes habían cometido diabluras durante el asalto, junto a caballeros, hombres de paraje y ciudadanos, lo cuales -ahora- azuzaban a los menestrales contra el gobierno municipal ${ }^{16}$. Con ello se comprobaba que poderosas personas estaban interesadas en evitar las pesquisas y los castigos, quizás porque habían participado en los hechos directa o indirectamente, a través de parientes o afines, quizás porque comulgaban con las ideas del arcediano.

Eliseo Vidal se hizo eco de las informaciones condensadas en la correspondencia de los jurados durante los meses posteriores, con las que pudo poner de manifiesto la abierta oposición - presentada contra los jurados y ante el rey- de un amplio grupo vecinal, que se decía más numeroso y mejor que el gobernante. De forma indirecta, y a través de las reacciones de los jurados, podemos conocer que los descontentos, de Valencia, de Alzira y de Morvedre, habían escrito a Juan I para presentar su propia interpretación del asalto y los deméritos del gobierno municipal. E incluso llegaron a acusar al hijo de Nicolau Valldaura, notable patricio y entonces jurado, de haber intervenido en el ataque y de haber huido hasta Gandia con treinta mil florines de

${ }^{14}$ Cfr. Jaume Riera, "Los tumultos ...”, p. 222-223; y "Estrangers ...”, p. 579. También Francisco Danvila, "El robo de la judería...", p. 375.

${ }^{15}$ El indulto real sería suscrito por Juan I el 8 de noviembre de 1392 y tan sólo preveía la ejecución de cinco de los presos encarcelados. Otras veinte personas, ausentes de la ciudad, fueron culpabilizadas por el consell, las cuales serían desterradas y, en caso de retornar, condenadas a muerte en la horca o decapitados si fueran caballeros, cfr. Francisco Danvila, "El robo de la judería ...", doc. 31, p. 395. El mismo autor pudo leer i transcribir alguna de las encuestas promovidas por Pere de Luça, asesor delegado por el rey para recibir las alegaciones de los perjudicados en el asalto, como la de Joan Pérez de Sent Jordi olim Jucef Abarim, quién relato el asalto de su domicilio, el asesinato de sus parientes y el forzamiento de las mujeres de la familia, llegando a dejar constancia de que entre los atacantes había "alcun home de condició", cfr. doc. 25, pp. 390-391. Sobre la rivalidad entre el justicia y el gobernador por arrogarse la competencia jurisdiccional cfr. AMV, Manuals de consells A-19, fol. 251v-253v (6 agosto 1391). La lista de culpabilizados por el asalto, proporcionada por el consell, incluía a veinte personas de condición menestral, salvo el fraile Berenguer de Montoliu, aunque algunos apellidos delatan su origen castellano, cfr. AMV, Manuals de consells A-20, fol. 38-39 (15 noviembre 1392). Inmediatamente después el consell hacía pregonar la inminente llegada del rey a Valencia y ésta se preparaba para organizar la festividad ceremonial (fol. $39 \mathrm{v})$.

16 Sobre la participación de los frailes cfr. AMV, Letres misives g3-5, fol. 28v-29 (22 julio 1391); y sobre los caballeros, el comendador de Coves de Vinromà y demás cfr. Ibidem, fol. 37-37v (5 agosto 1391). 
botín para buscar amparo en el marquesado de Villena. Después, llamado por su padre, regreso a Valencia para disentir de la acusación y, finalmente, cuando Nicolau Valldaura y micer Ramon de Soler se presentaron ante la corte real en Barcelona, el rey ordenó prender a dos hijos del primero ${ }^{17}$.

Mientras tanto, algunos vecinos de Alzira difundían serias acusaciones contra los jurados de Valencia, a quienes señalaban por haber pactado con el infante Martín el ajusticiamiento expeditivo de nueve personas para evitar la ira real. Tres serían de la mano menor, tres de la mediana y además se incluiría a tres caballeros, los cuales habían sido presos por el infante Martín como responsables del asalto de Valencia: Carroç, Huc de Bordils y Pere de Siscar ${ }^{18}$. También se decía que los jurados habían matado de hambre a siete de los encarcelados por el asalto. Más tarde, Juan I se mostró indignado porque los jurados habían encarcelado a Tomas Carbonell, y porque Ferran Ximènez alias Galceran de Riu-sec y En Rosell habían tenido que huir a toda prisa de Valencia para evitar idénticas represalias. De estos últimos se decía que habían comenzado a promover un movimiento sedicioso entre los artesanos de la capital, alentándolos con las promesas de que podían gobernar la ciudad, ocupar las magistraturas de jurados, inspeccionar las cuentas de la hacienda municipal en los últimos veinte años y buscar responsabilidades. Todo ello porque el infante Martín había logrado avenir al brazo militar con la ciudad de Valencia por el enfrentamiento que los separaba, como bien analizaremos más adelante ${ }^{19}$.

17 El 28 de diciembre de 1391 los jurados remitían varias cartas a diferentes personalidades de la corte para presentar y avalar la misión de los síndicos de Valencia. Ramon Almany de Cervelló, consejero, carmarlengo y gobernador general de Cataluña; la misma reina Violant de Bar; Pere Maça de Liçana; Bertomeu Sirment; el abad de Ripoll; y el tesorero real, Julià Garrius, fueron informados de la llegada con objeto de lograr apoyo a los negocios que iban a desarrollar, cfr. AMV, Letres misives g3-5, fol. 77-78. Entre otros asuntos, sobresalía uno bastante delicado: evitar y desmentir las falsedades y las acciones de los enemigos de los jurados de Valencia en la corte, cfr. Idem, fol. 78 (30 diciembre 1391). De hecho, días después, los jurados recriminaban a Ramon Alamany de Cervelló y a Pere Maça de Liçana que no hubieran intervenido o impedido el encarcelamiento de los hijos de Nicolau Valldaura en la corte, presos bajo acusación de haber participado en el asalto de la judería. La medida derivaba del "enginy, tractament, engàs (engarce) e encara promissió de valença e d'ajuda d'alcuns grans e mals hòmens, dels quals ha hui en la cort del senyor rei", los cuales estaban mantenidos y favorecidos por malvados, que a su vez difundían falsedades e infamias contra la ciudad y sus magistrados, cfr. Idem fol. 84-84v (24 enero 1392).

18 AMV, Letres misives g3-5 fol. 34 (28 julio 1391).

${ }^{19}$ Con la relectura de las cartas citadas por Eliseo Vidal Beltrán podemos recomponer un mosaico de noticias, asumidas siempre desde la perspectiva de los jurados: para defender la benemérita posición de Nicolau Valldaura y su familia (AMV, Letres misives g3-5, fol. 30v-31: 26 julio 1391); para contradecir las infamias propagadas por un grupo vecinal de Alzira, los "trentins", es decir, los treinta y tantos declarados responsables del asalto de aquella judería, solidarizados y agermanados con los enemigos de los jurados de Valencia (Idem, fol. 33-34: 28 julio 1391); para constituir una secuela, partido o grupo de presión muy bien escuchado en la corte real (Idem, fol. 35-36: 29 julio 1391); para evitar a toda costa un pacto entre la ciudad y el brazo militar en el contencioso que entonces los separaba (Idem, fol. 42-43: 13 agosto 1391); para azuzar a los menestrales contra el gobierno municipal, bajo el liderazgo de Ferran Ximènez, En Rosell y En Guardiola (Idem, fol. 44-44v: 19 agosto 1391); y para formar un grupo contrario a los jurados capaz de reunir -según aducían- una fuerza de trescientos a caballo (Idem, fol. 53-55: 11 septiembre 1391), cfr. Eliseo Vidal Beltrán, Valencia en la época de Juan I, Valencia, Universidad, 1974, pp. 59-65. 


\section{LA CRECIENTE HOSTILIDAD HACIA LA JUDERÍA}

Los límites de la primitiva judería en una zona interior respecto a la muralla islámica fueron dibujados por José Rodrigo Pertegás, quien recogiendo las informaciones de las fuentes municipales y notariales demostró como, a mediados del siglo XIV, los judíos habían rebasado con mucho sus confines y se habían domiciliado de facto mediante compras y alquileres en las calles adyacentes, pertenecientes a las parroquias de san Andrés, de santo Tomás y de san Esteban, así como en los aledaños de la iglesia de san Juan del Hospital, lo que sirvió de pretexto al gobierno municipal para intentar el nuevo cercamiento del barrio y la consiguiente ampliación del mismo ${ }^{20}$.

Ya las actas de cortes reflejaron quejas en tal sentido, pues el 24 de septiembre de 1371, denunciaban que los judíos habían comprado, seguían comprando y alquilaban casas fuera del recinto que tenían asignado. En la misma reunión el brazo real exigió la extinción del mostassaf de la aljama hebrea y el de la mudéjar, consentidos poco antes por la reina. Más tarde, el 2 de enero de 1386, Pedro el Ceremonioso se pronunció a favor de las protestas formuladas por los párrocos de santo Tomás y de san Andrés, porque los judíos habían comprado, compraban y residían en sus distritos, mezclándose con los cristianos. Estas circunstancias crearon un ambiente de hostilidad, contrario al crecimiento de la judería y al consiguiente repliegue de los vecinos cristianos $^{21}$.

Finalmente, la ampliación de los límites topográficos de la antigua judería fue aprobada en las cortes de 1389, lo que permitió no sólo la ampliación de su perímetro sino la ocupación de un espacio nodal en la ciudad, porque desde las primeras décadas del siglo se había venido produciendo un progresivo aumento de la población en el barrio hebreo ${ }^{22}$. En realidad, la clausura integral del barrio -ordenada en 1371-

20 José Rodrigo Pertegás, La judería de Valencia, Valencia, F. Vives Mora, 1913, reproducción facsímil de Librerías París-Valencia, 1992, en especial el plano de la p. 28, el cual ha sido utilizado como base para nuestro mapa de situación. Sobre la delimitación de las calles en la primitiva judería y su ampliación cfr. pp. 5-9. Una secuencia detallada de los planos puede verse en Marilda Azulay - Estrella Israel, La Valencia judia: espacios, límites y vivencias hasta la expulsión, València, Consell Valencià de Cultura, 2009, pp. 332-338.

21 José Hinojosa Montalvo, En el nombre de Yaveh. La judería de Valencia en la Edad Media, Valencia, Ayuntamiento, 2007, pp. 63, 68 y 71-74, donde recopila la información referida y se incluyen nuevas referencias documentales de la cancillería real, respecto a las actuaciones, procedimientos y resoluciones arbitradas respecto al asalto. También del mismo autor, "La comunidad hebrea de Valencia: del esplendor a la nada (1377-1391)", Saitabi 31 (1981) pp. 47-72. También cfr. Eliseo Vidal, Valencia en la época de Juan I, pp. 17-19.

22 Sobre la considerable ampliación del barrio cfr. Francisco Danvila y Collado, "Clausura y delimitación de la judería en Valencia en 1390 a 1391", BRAH 18 (1891) pp. 142-159. Un ejemplo de la animosidad contraria a los judíos, desatada por la ampliación del barrio, lo proporciona el conflicto entablado entre la iglesia de san Juan del Hospital y el propio municipio por las obras de reacondicionamiento de sus aledaños en 1388. Desde el mes de febrero Arnau Armengol, comendador de Torrent, y Guillem Alja, presbítero y diácono de la iglesia, Domingo Gil, prior de la casa, Mateu de Boles, Miquel Bru, Gombau Martí y Berenguer Font, presbíteros, se opusieron a la adjudicación en favor de los judíos de la zona urbanizada en el entorno de la iglesia, alegando distintas razones: que había estado tradicionalmente habitada por cristianos, los cuales abandonaron el lugar por la instalación de los hebreos; que el acceso a la iglesia estaba dificultado por los muchos pecados que cometían sus nuevos ocupantes; que la zona estaba en un estado ruinoso y que tras las obras había quedado sólidamente 
nunca había sido concluida por aquel continuo rebasamiento de los lindes y, en 1389, el renovado deseo de cierre extendía de forma extraordinaria el espacio tradicionalmente ocupado. De ese modo, la orden de nuevo cerramiento del barrio, aprobada en las cortes, reconocía de iure la presencia de los hebreos donde ya estaban asentados y la más que notable ampliación urbana de la judería.

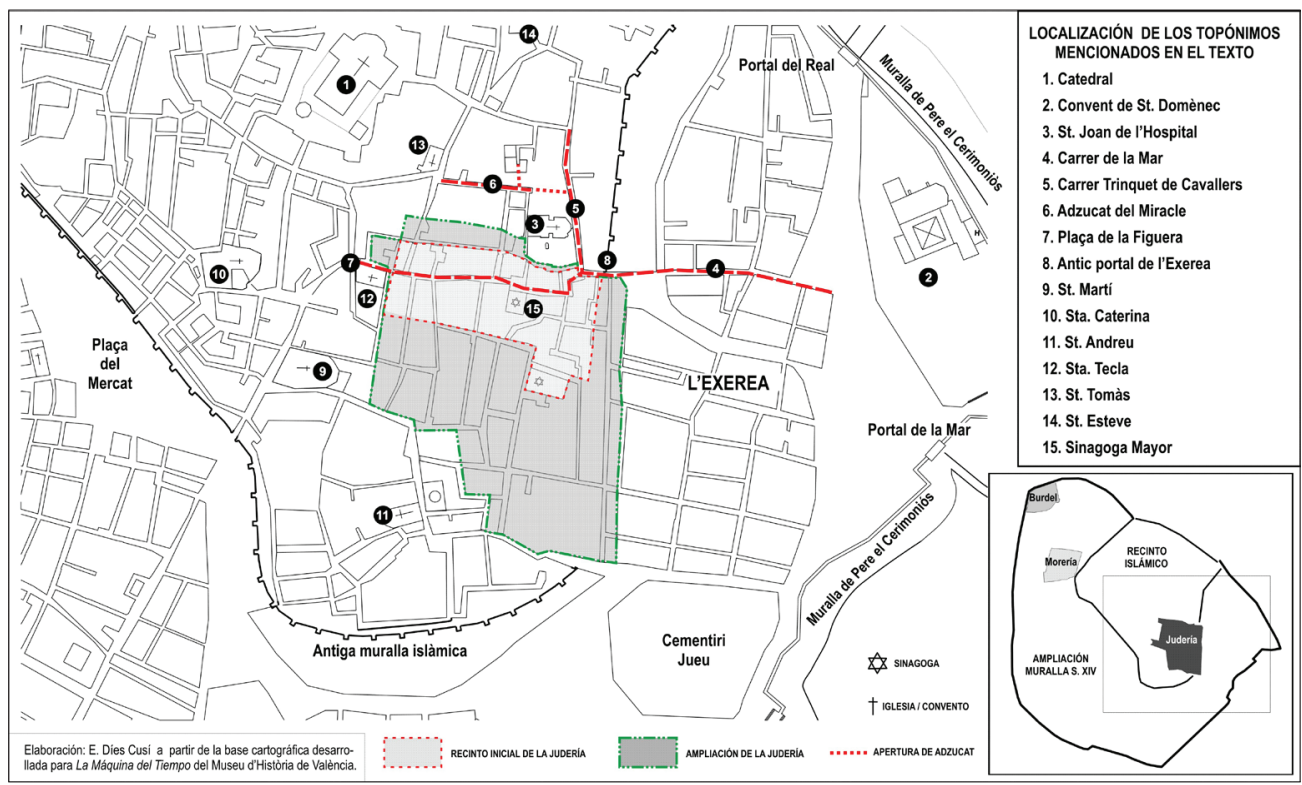

El nuevo muro de tres palmos de ancho y suficiente altura, más el perfilado exterior del barrio exigieron acometer expropiaciones cuando no el tapiado de calles, puertas y ventanas en los domicilios de los cristianos colindantes, engendrando no pocas protestas, que obligaron a los comisarios reales a rectificar el proyecto inicial y prever la transformación en calle del callejón o adzucat del Milagro, lo cual redundó en la creciente impopularidad de la medida entre los afectados por las nuevas expropiaciones. Por otro lado, según se comprueba, las continuas quejas de los vecinos de la Exerea y del Convento de Predicadores surgían por el tapiado de la calle que unía el centro de la ciudad con el Portal de la Mar y el Grau, siendo paralela a la calle del Mar, eje axial de una urbe portuaria que continuaba por el interior mismo de la judería. En

renovada para mejora de la ciudad y, por tanto, no podía ser adjudicada a los judíos, quienes deberían ser castigados por sus crímenes y no remunerados de ese modo, pues si se les premiaba de tal manera los cristianos injuriaban a Dios, a san Juan y a toda la cristiandad; también rogaban que la zona fuese devuelta a su estado original y con ello evitar el oprobio de los vecinos cristianos, tal y como debía procurar el gobierno de la ciudad para lograr el bien de la Iglesia, de la cristiandad y de la cosa pública. Todo un conjunto de razones argumentadas para conseguir la expulsión de los judíos de la calle próxima a la iglesia y, a la vez, conseguir el cierre y limitación correcta de la judería. Cfr. Archivo del Reino de Valencia, en adelante ARV, Notal de Jaume Mestre 2639 fol. 19-26v (13 febrero 1388). Sobre la ocupación del callejón, después calle del Milagro, por vecinos judíos, así como en los aledaños de la parroquia de san Esteban, cfr. José Rodrigo Pertegás, La judería de Valencia, pp. 5-6. 
ambos casos, se limitaba el tránsito vecinal y se provocaba el práctico aislamiento de los dominicos respecto al resto de la ciudad. A finales de ese mes el consell ordenaba el derribo de algunas casas tocantes con la judería para el evitar acceso a la misma desde las terrazas cristianas, dadas las alarmantes noticias que llegaban desde Castilla. Etc. ${ }^{23}$. Es decir, tanto la ampliación y amurallado del barrio exigieron obras muy problemáticas, que llegaron a necesitar el concurso de una guardia específica del justicia con el fin de proteger a los obreros de la violencia de los vecinos. Según reitera José Rodrigo Pertegás la última clausura ordenada en 1389 difícilmente llegaría a concluir sus obras por la inmediatez del asalto, debiendo valorarse como elemento importante en el desencadenado furor ${ }^{24}$.

Sin embargo, todas las circunstancias referidas -aún afectando de forma centrípeta y directa a la aljama- vinieron a coincidir con otros fenómenos colectivos que afectaban al pulso político y social de la ciudad en aquel nefasto 9 de julio, sin duda concurrentes con la evolución de los acontecimientos, a los que cabría prestar mayor atención para entender mejor cómo se llegó a gestar aquella primera explosión de violencia en la Corona de Aragón. Para ello deberíamos retraernos al menos tres años atrás y relacionar la compleja trama de conflictos que embargaban entonces al municipio. Tras comprobar la amplitud de su impacto, resulta difícil considerar que esos antecedentes no afectaran de alguna manera a aquel pogromo, ahora que conocemos con detalle sus consecuencias, pues si poco antes del mismo asalto se engendraron diversas situaciones de significada conflictividad, poco después de la agresión terminaría desatándose una cruenta lucha de bandos en el seno de la clase dirigente y de la misma ciudadanía. ¿Por qué buscar las causas del asalto dentro la judería y entre quiénes ejercieron de sujeto paciente? ¿Por qué no entre quiénes lo protagonizaron?.

\section{LAS CORTES DE 1388-1389}

El miércoles 1 de diciembre de 1389, a mediodía, Juan I expresaba su deseo de concluir momentáneamente las sesiones de las cortes generales de la Corona que venían desarrollándose desde poco más de un año en Monzón y, de este modo, prorrogar su consecución dos meses después. La urgencia de repeler la presencia de tropas extranjeras en suelo catalán había sido pretextada para lograr la suspensión de unas cortes muy polémicas. Casi en el último momento, los tres brazos del reino de Valencia ofrecieron un sustancioso donativo o préstamo para hacer frente a los primeros gastos de la movilización y, al mismo tiempo, la ciudad de Valencia solicitaba del monarca la concesión de algunas mercedes. Entre ellas, figuraba en primer lugar la

${ }^{23}$ Sobre las características del muro "de III palms de grossos e ben alt", con cinco metros de altura y setenta centímetros de ancho, cfr. Francisco Danvila, "El robo..." doc. 4, p. 381; y Manuel Carboneres Nomenclátor de las puertas, calles y plazas de Valencia, Valencia, Imprenta el Avisador Valenciano, 1873, p. 14. Sobre el pago de salarios a quienes planificaron los límites y las expropiaciones, cfr. AMV, Manuals d'albarans de claveria comuna I-18, fol. 25, 28v, 29v y 35v. Sobre las expropiaciones y derribos cfr. Ma Milagros Cárcel Ortí - José Trenchs Odena, "El Consell de Valencia: disposiciones urbanísticas (siglo XIV)", en La ciudad hispánica durante los siglos XIII al XVI, Madrid, Editorial Complutense, 1985, vol. 2, doc. 225 (5 marzo 1390), doc. 244 (4 marzo 1391) y doc. 248 (27 junio 1391).

${ }^{24}$ José Rodrigo Pertegás, La judería ... p. 5, 10 y 12. 
propuesta de clausurar y limitar la judería de la capital, porque el antiguo fuero de Pedro el Ceremonioso nunca había sido puesto en práctica de forma integral, según los motivos aducidos anteriormente, razón por la que dos jurados de Valencia y dos comisarios reales (mosén Francisco de Aranda y Miquel Dapiera, baile de la judería), arbitrarían y velarían por llevar a término aquel renovado objetivo. Es decir, el cierre era solicitado en las cortes por los propios síndicos de Valencia, cuando suponía un extraordinario aumento de su superficie en una zona demasiado central de la ciudad y no en uno de sus extremos, tal y como originalmente fue concebido el barrio de la judería. Con las restantes peticiones aquellos síndicos pidieron y consiguieron del rey la capacidad para comprar y ajusticiar moros corsarios ${ }^{25}$; el permiso necesario para sustituir la designación directa de lugartenientes del justicia criminal y del mostassaf por un sistema sorteado; la corroboración de la negativa a alinear patrimonio regio en la frontera, en especial en Biar y Ontinyent, exceptuándose el tercio diezmo de esta última localidad; la exención de pagar los derechos del sello al protonotario por los capítulos otorgados; y la facultad para elegir a dieciocho representantes de los tres brazos del reino para que a su vez designaran a los diputados y clavarios del general, encargados de la recaudación del donativo. Juan I tan sólo se negó a ratificar la donación de los impuestos a las villas reales ${ }^{26}$.

Pese a los resultados favorables aquellas cortes habían sido especialmente difíciles para los valencianos. La iniciativa contra Carroça de Vilaragut, puesta en marcha por algunos nobles y caballeros junto a los representantes del brazo real de Cataluña, había logrado poner fin y expulsar de la corte a la que consideraban una perniciosa influencia sobre los monarcas, al haber sido acusada de corrupción y de favorecer la destrucción del patrimonio real. El marco de aquella moción de censura lo proporcionaron las intrigas y los continuos choques entre los consejeros más allegados a Juan I y a su esposa (García Fernández de Heredia, arzobispo de Zaragoza; Roger de Moncada, camarero real; Pere y Hug Alamany de Cervelló; Pere Maça de Liçana,

${ }^{25}$ El motivo alegado para obtener aquel derecho se comprueba en una decisión del consell, sólo dos días posterior: el 3 de diciembre de 1389 se compraban cinco moros de Berbería para ser ajusticiados públicamente, alegando que aquéllos habían participado en la sublevación de Orán el año anterior, donde fueron robados y asesinados los mercaderes cristianos, algunos de Valencia. Cfr. AMV, Manual de consells A-19, fol. 88-88v.

${ }_{26}$ Se ofrecieron como préstamo o donativo a Juan I 13.708 florines en seis meses y éste se comprometió a retomar las cortes en cuanto expulsara a las tropas extranjeras. Cfr. Acta curiarum regni Aragonum, tomo V. Cortes de los reinados de Pedro IV/4 y Juan I. Cortes Generales de Monzón 13881389, edición a cargo de J. Ángel Sesma Muñoz, Zaragoza, Gobierno de Aragón, 2009, pp. 449-454. La petición es elocuente a la hora de indicar la clausura de la judería ordenada en tiempos de Pedro el Ceremonioso: "e d'açò sien stades fetes en temps passat alcunes comissions als jurats de la dita ciutat e a altres, les quals per importunitat o en altra manera són stades variades o empatxades", cfr. Idem, p. 453. Idéntico texto y conjunto de medidas se encuentran recopilados en "Capitols oferts per les ciutats e viles del regne" en los fueros de Valencia aprobados en las cortes de Monzón de 1389 por Juan I, cfr. Furs e ordinacions fetes per los gloriosos reys d'Aragó als regnicols del regne de València, València, Universitat, 1977, pp. 354-356. Los diputados del general del reino de Valencia, aplicando los capítulos elaborados en Valldigna por los dieciocho electos en las cortes de Monzón, decidieron la recaudación del donativo mediante generalidades, las cuales serían vendidas a arrendadores-recaudadores en subasta pública en Valencia. No obstante, los ramos del tall del drap y gabella de la sal, de fuera del reino, se subastarían en lugares específicos. Cfr. Archivo de Protocolos del Patriarca de Valencia, en adelante APPV, Notal de Joan de Sentfeliu 51 fol. 9-9v (18 abril 1390). 
y otros, junto a Carroça), y los acólitos de Alfonso de Aragón, marqués de Villena, condestable de Castilla, conde de Dénia y Ribagorza y futuro duque de Gandia, entre los que se contaban sus dos hermanos, Jaume d'Aragó, obispo de Valencia entre 1369 y 1396; y Joan d'Aragó, conde de Prades y senescal de Cataluña, quien llegó a acusar al caballero Francisco de Aranda en 1388 de envenenar al neonato Fernando, primogénito real, entonces enfermo y pronto fallecido, e incluso al mismo monarca, dado su delicado estado de salud, sin otro fin que transmitir el trono al infante Martín. El grupo apartado de la esfera íntima de los monarcas contaba con el apoyo de los partidarios de Sibil la de Fortià, última esposa del Ceremonioso, y de una nómina de nobles y caballeros entre los que se contaban, entre otros, Joan Bellera, Pere y Berenguer de Vilaragut. La rivalidad desatada por lograr el favoritismo y la privanza en la administración del reino, junto a las prebendas anexas, desataron las reivindicaciones de buen gobierno y las acusaciones de malversación o corrupción, pero fue el rechazo de la propuesta de la Nova ordinació de justícia en aquellas mismas cortes, lo que engendró la reacción nobiliaria, pronto centrada en los ataques contra Carroça de Vilaragut ${ }^{27}$.

Aquella propuesta de expulsión consiguió la adhesión de los síndicos enviados por Valencia. El 3 de octubre de 1388 el consell había escogido como emisarios a Pere Joan y a micer Bonifaci Ferrer, jurados, más Joan Suau, menor, Berenguer de Rabinats y Jaume Romeu, ciudadanos ${ }^{28}$. En su misiva del 20 de julio de 1389 éstos notificaron al consell las novedades promovidas y lideradas por Alfonso, marqués de Villena, y también por Hug de Llupià, obispo de Tortosa entre 1379 y $1397^{29}$. El consell remitió instrucciones para que sus representantes apoyaran a los brazos del reino de Valencia y, sino existía unanimidad entre ellos, que sustentaran la causa común de las villas y ciudades del brazo real. Pero el 23 de julio, mediante una misiva, Juan I se quejaba ante el consell de la postura contraria y reivindicativa que defendían sus síndicos, lo que provocó la decisión de revocarlos en la reunión municipal de 20 de agosto. Fue entonces cuando fueron sustituidos por Nicolau Valldaura, micer Guillem Çaera, Jaume Marrades y micer Joan Mercader. Días después, el 31 de agosto el consell decidía procesar por traición a los primeros emisarios, iniciándose un largo pleito entre el síndico de la ciudad y sus antiguos portavoces en las cortes ante el tribunal de la gobernación,

27 Cfr. Francisco Danvila y Collado, Na Carroça de Vilaragut. Estudio biográfico, Madrid, Establecimiento tipográfico de Fortanet, 1888, pp. 15-33. Sobre la formación de dos grupos enemistados en la corte real, las acusaciones de desgobierno, la resistencia de los síndicos a someterse a la voluntad regia y la reivindicación de éstos de participar en la elección de canciller y de consejeros del monarca, cfr. Ferran Soldevila, Història de Cataluña, Barcelona, Alpha, 1962, vol. 2, pp. 496-504; y Josep Maria Salrach, Història dels Països Catalans, Barcelona, Edhasa, 1981, vol. 2, pp. 772-774; y M ${ }^{\mathrm{a}}$ Teresa Ferrer i Mallol, "Un aragonés consejero de Juan I y de Martín el Humano: Francisco de Aranda", Aragón en la Edad Media 14-15 (1999), Homenaje a la profesora Carmen Orcástegui Gros, vol.1, pp. 531-562, en especial pp. 534-535.

${ }^{28}$ Cuando fue designada esta comisión de síndicos eran jurados: Joan Suau, mayor; Pere Joan; micer Bonifaci Ferrer; y Nicolau Valldaura; más los dos caballeros, Guillem de Jàfer y Joan de Ripoll. Estando en Monzón, Jaume Romeu fue elegido jurado para 1389, junto a otros tres ciudadanos: Pere Pasadores, Leonard Marrades y Jaume Valleriola; y dos caballeros: Joan Fabra y Joan de Jàfer.

${ }^{29}$ El obispo junto a los demás críticos había abandonado las cortes como medida de protesta, cfr. las actas citadas del proceso p. 393. Sobre las fechas indicadas cfr. AMV, Manuals de consells A-19, fol. 21 (3 octubre 1388), fol. 59-59v (20 julio 1389), fol. 61-62 (23 julio 1389), fol. 68-68v (20 agosto 1389), $\mathrm{y}$ fol. $69 \mathrm{v}-70$ (31 agosto 1391). 
desencadenando la división de las elites políticas y, con ello, una profunda división en el seno de la sociedad valenciana, que terminaría dando cuenta de una cruel lucha entre dos bandos enemistados, conformados -uno y otro- por caballeros y ciudadanos ${ }^{30}$.

Entre aquel proceso y el cruento conflicto se produjeron algunos acontecimientos susceptibles de ser anotados. El 29 de marzo de 1390, Sarrovira, pañero que regentaba el obrador de Joan Suau difamaba a los nuevos síndicos hablando a favor de los primeros y, según consideraba el consell, sus palabras podían promover discordias y sediciones entre el pueblo, previéndose su castigo como propagador de cizañas. Meses después, el 23 de julio, las esquinas y las paredes de la ciudad aparecieron cubiertas de carteles y epitafios a favor de los síndicos procesados. Y el 16 de noviembre de aquel mismo año el consell expresó su voluntad a favor de que los procesados fueran sometidos a tormentos judiciales para que éstos confesasen sus crímenes sin dilaciones, lo que motivo un alud de improperios por parte de los encausados ante el mismo tribunal, contra el síndico de Valencia, y contra los magistrados en activo de la capital, los cuales ponían en entredicho su honorabilidad y atentaban contra su buena fama ${ }^{31}$.

Sin embargo, el asalto de la judería reactivó la estratégica defensa de los síndicos procesados por traición. Fueron ellos, los "delats", los que hicieron causa común y "germania" con los inculpados en el asalto de la judería de Alzira contra los jurados de Valencia ${ }^{32}$. También fueron ellos quienes se declaraban más numerosos y mejores que los regidores de la capital, e incluso quienes apoyaban a los caballeros, ciudadanos y menestrales presos como responsables del asalto en Valencia, a la vez que atribuían el desastre y nula protección de la judería a la incompetencia y mala voluntad de los jurados. Conviene recordar que esos síndicos procesados por traición habían logrado del rey el permiso para la ampliación del barrio y que los jurados elegidos durante su estancia en Monzón fueron quienes los destituyeron y procesaron, los cuales aún mantenían plena ascendencia sobre los jurados en ejercicio cuando se produjo el asalto. Por su parte, los jurados acusaban la falsedad de las acusaciones proferidas ante el rey y también la connivencia de estos "delats" con los apresados por el asalto:

\footnotetext{
"e pot-se dir amb veritat que ls hòmens que més basquen (se afanan o sufren) per la presó d'alcuns preses per aquest fet de la juheria són alcuns de la part dels delats, tot savi entenent, e axi es veritat, que hòmens hi ha preses de llur part qui ls coen molt e massa, e que són culpables, e per ço, basquen" "33.
}

${ }^{30}$ Miguel Llop Català, "Proceso a Bonifacio Ferrer", Escritos del Vedat 10 (1980) pp. 415-471. También mis trabajos "L'Interregne a València", Congrés Internacional Martí l'Humà, el darrer rei de la dinastia de Barcelona (1396-1410). L'Interregne i el Compromís de Casp, (31 maig-4 juny de 2011), organitzat per l'Institut d'Estudis Catalans- CSIC, en prensa; y "Las elites políticas valencianas entre el Interregno y el Compromiso de Caspe", en La Corona de Aragón en el centro de su historia. El Interregno y el Compromiso de Caspe (1410-1412), Zaragoza, Gobierno de Aragón, 2011, pp. 191-232.

${ }^{31}$ Sobre Sarrovira cfr. AMV, Manuals de consells A-19 fol. 118v (29 marzo 1390); sobre los carteles y epitafios fol. $155 \mathrm{v}-156$ (23 julio 1390); y sobre los insultos a los jurados y consejeros de Valencia fol. 180-181v (16 noviembre 1390).

${ }^{32}$ AMV, Letres misives g3-5 fol. 33v (28 julio 1391).

33 AMV, Letres misives g3-5 fol. 35v (29 julio 1391). 
Además, esos mismos personajes participaban en el proyecto de sublevar al pueblo contra los jurados, "ço induexen molts del poble a desgrat e malèvolença contra nosaltres" 34 .

El larguísimo pleito de traición contra los primeros síndicos enviados a las cortes generales de Monzón sólo concluiría con el acceso al trono de Martín el Humano en 1396, quien no sólo promovió un rotundo cambio en la corte real y sino también en el gobierno de Valencia, ya que los acusados no sólo fueron rehabilitados como ciudadanos honorables sino que los encontramos completamente reincorporados a la vida política municipal en aquellos años: Berenguer de Rabinats fue elegido consejero de la parroquia de santa Catalina en 1398; en 1402, Pere Joan fue jurado y Joan Suau conseller de la parroquia anterior; Jaume Romeu, en 1405, no sólo había sido promocionado al rango de caballero sino que fue designado consejero en los escaños que la ciudad reservaba a aquéllos; y Bonifaci Ferrer, en 1398, libre de todo cargo, ya había profesado cartujo en Portaceli, donde coincidió con otro nuevo donado: Francisco de Aranda, antiguo comisario real para ampliar la judería de Valencia. Bonifaci y Francisco fueron designados compromisarios para asistir a la declaración de Caspe y, también, sintonizaron a la hora de emitir su voto a favor del infante Fernando.

\section{LA MONARQUÍA Y LOS HEREJES}

Ya en 1375 Pedro el Ceremonioso había reaccionado de forma contundente contra los irregulares procedimientos empleados por Nicolau Eimeric, inquisidor pontificio en la Corona de Aragón, al haber aplicado un rigor extremo a los seguidores de las doctrinas de Ramon Llull. El dominico fue desterrado de los dominios reales y considerado enemigo del bien y de sus reinos el 11 de marzo de aquel mismo año. Sin embargo, Eimeric no cejó en su continuo velar por la pureza de la fe y el consecuente expurgo de la herejía y, desde Aviñón, redobló sus actividades. En 1376 terminaba el Directorium inquisitorum, un manual que pretendía pautar el correcto y riguroso quehacer de los jueces del tribunal, y esgrimiendo una bula otorgada por Gregorio XI el 25 de enero de 1376, mediante la cual se condenaban veinte obras de Llull, se tachaban como heréticos doscientos artículos, y se ordenaba la confiscación de todos sus libros para ser sometidos a un riguroso examen ${ }^{35}$. Se iniciaba así la larga controversia luliana en la Corona de Aragón en la que quedaron implicados el monarca, el pontificado, el inquisidor y el infante Juan, un problema acentuado por el progresivo distanciamiento entre el Ceremonioso y su heredero, ya que entre los acólitos del infante encontraron muy buena acogida las radicales tesis de Eimeric y, de hecho, el dominico gozó de la protección del duque de Gerona hasta $1388^{36}$.

El Manual de los Inquisidores constituía una síntesis de la doctrina jurídica de la Iglesia, un tratado sistemático que recopilaba y elaboraba las pautas que habrían de seguirse para el celoso ejercicio de la función inquisitorial, una obra clara y eficaz, sin

34 AMV, Letres misives g3-5 fol. 37 (5 agosto 1391).

35 Andrés Ivars, "Los Jurados de Valencia y el inquisidor fray Nicolás Eymeric", Archivo Iberoamericano VI (1916) pp. 71-72.

36 Idem, pp. 78-79. 
recursos estilísticos o teológicos. En ella Eimeric aprovechó los cánones que durante siglos habían sido enunciados para dotar las competencias pontificias en materia de fe y de erradicación de la herejía ${ }^{37}$. Es decir, las fuentes jurídicas empleadas por el dominico legitimaban una apreciación integral de la misión de la Iglesia en los asuntos de persecución y represión de aquéllos que atentaran contra el credo católico. Para Eimeric herejes eran quienes elegían el error, se obstinaban en él y, con ello se apartaban de la comunidad de creyentes, quedando incluidos entre esos, los infieles, los paganos, los musulmanes y los judíos, pues atentaban contra la universalidad de la fe católica y de la Inquisición ${ }^{38}$. Por esta razón, en la primera parte de la obra, dedicada a la jurisdicción del inquisidor, el autor se ocupaba por definir la noción de herejía, según la cual alcanzaba algunas conclusiones: "el hereje elige entre una doctrina verdadera y una falsa, rechaza la verdadera doctrina y elige por verdadera una doctrina falsa y perversa"; eran herejes quienes se oponían a la Iglesia; y ésta también extendía su jurisdicción a aquéllos que se oponían a la fe cristiana, dado que el pontífice, como vicario de Cristo no sólo ostentaba el poder sobre los cristianos sino sobre todos los infieles, pues se consideraba que el poder de Cristo era universal y se proyectaba sobre todos los hombres, los cuales por el mero hecho de haber sido creados eran ovejas de Cristo, aun cuando no pertenecieran al rebaño de la Iglesia. En consecuencia, el poder papal no debía de abstenerse de castigar a los gentiles que se oponían a la ley natural y, por supuesto, debía condenar los casos en los que el poder temporal protegiese a los judíos. La Inquisición debía actuar contra los que albergasen, acogiesen, recibiesen o fueran bienhechores - por acción u omisión- de los herejes ${ }^{39}$.

Buena prueba de los oídos que se prestaban a las proposiciones de Eimeric en el círculo de consejeros que rodeaban la corte del infante Juan se atesta en 1377, cuando el duque de Gerona llegó a Aragón y se dispuso a dar fin a los procesos civiles y criminales en calidad de gobernador general. Se iniciaba entonces el proceso contra unos judíos de Huesca acusados de comprar cinco hostias sagradas a un cristiano que, al parecer, las había robado en la iglesia de Tardienta ${ }^{40}$. Lo cierto es que años atrás Pedro el Ceremonioso había recriminado a su hijo que se dejara llevar por el criterio de una interesada camarilla de consejeros, entre cuyos propósitos sobresalía el de perjudicar a las aljamas hebreas, sin tener en cuenta -aducía el rey- que estas acciones empobrecían el patrimonio real. Aquella posición abiertamente antijudaica se man-

37 Nicolau Eimeric - Francisco Peña, El manual de los inquisidores, introducción, traducido del latín al francés y notas por Luis Sala-Molins, traducción del francés por Francisco Martín, Barcelona, Muchnik Editores, 1996, pp. 15-23. La obra original de Eimeric fue completada, desarrollada y actualizada por Francisco Peña, por encargo del general de los dominicos y el comisario general de la inquisición romana "en nombre del senado de la Inquisición romana" en 1578. No obstante, la edición citada deslinda con precisión los textos de Eimeric de los añadidos por Francisco Peña, siguiendo la pauta de trabajo establecida por el propio comentarista del Quinientos. El libro sería impreso en Roma en 1585 y sucesivamente, constituyendo -como su propio nombre indica- una guía que pretendía homologar el comportamiento de los inquisidores en todos los tribunales.

${ }^{38}$ Cfr. Manual de los inquisidores, p. 38, 44 y 47.

39 Estas ideas quedan enunciadas en el Manual de los inquisidores, p. 57, 61, 89-90, 92 y 100-102.

40 Joaquim Miret i Sans, "El procés de les hosties contra·ls jueus d'Osca en 1377", Anuari de l'Institut d'Estudis Catalans IV (1911-1912) pp. 59-80. 
tenía viva en el entorno del primogénito heredero y dio lugar a un castigo expeditivo en diciembre de 1378 cuando, sin proceso ni defensa legal alguna, el infante condenó al ladrón a ser descuartizado y a los judíos que él había acusado a la hoguera, sin otro indicio criminal que la confesión bajo tortura del ladrón. Los hebreos también fueron torturados e implicaron con sus testimonios a otros tres judíos como profanadores de las hostias. Pronto el monarca hizo saber a su hijo que sus consejeros le habían engañado, dando credibilidad a aquel sacrilegio sin realizar ninguna investigación, e incluso alegaba que una acusación similar formulada ante él mismo tiempo atrás en Barcelona se había demostrado infundada y sólo sostenida en calumnias. En consecuencia, el Ceremonioso aconsejaba prudencia al infante y que no prestara oídos a los fanáticos que le rodeaban, los cuales le instaban a aplicar con rigor extremo la justicia penal sobre los procesados, pues -según el rey-el propósito de aquéllos no era otro que la destrucción de la aljama y de quienes la habitaban ${ }^{41}$.

Las crecientes diferencias entre el monarca y el heredero terminaron con la taxativa orden de remitir el proceso a la corte real en Barcelona. Tras un detenido análisis, el rey comunicó a su hijo que las irregularidades cometidas durante el proceso eran muchas y graves: según las confesiones, el ladrón vendió las hostias por treinta sueldos y tres anillos de plata de poco valor y, en cambio, no robó la custodia que las albergaba, valorada en cinco o seis florines de oro; la inculpación de los judíos era resultado de las torturas y fue alegada por el primer procesado para lograr su exculpación; la última declaración del ladrón, en la que negaba todo lo aducido bajo tortura y libraba de toda participación en los hechos a los judíos, no constaba en el expediente procesal; etc.; motivos por los que el rey ordenaba al infante la suspensión de los tormentos a los últimos incriminados y el sobreseimiento de la causa. Aquella desautorización pública de las acciones judiciales del infante iba acompañada de una evidente ridiculización, pues lo presentaba como un títere del que se servían unos malignos consejeros, sin otro fin que maltratar o acabar con los judíos. La respuesta de Juan acabó con un tono despectivo e insultante. El enfrentamiento entre padre e hijo fue duro y, finalmente, para lograr la reconciliación y no deslegitimarle en las funciones de gobernador el Ceremonioso devolvió el proceso al infante, aunque vinculando su seguimiento futuro a dos personas de su confianza: el noble Lope de Gurrea y Miguel Capiella, oidor de la corte real. Bernat Despont, el jurisperito regente de la cancillería del infante en Zaragoza, principal promotor del proceso, insultó al rey y Juan hubo de defenderlo para evitar la ira real. Desde ese momento, los consejeros del infante interesados en perseguir a los judíos de Huesca quedaron desautorizados, las diligencias fueron abandonadas y el proceso sobreseido. El distanciamiento entre el rey y el infante iría creciendo en los años sucesivos por nuevas intrigas cortesanas, sobre todo desde el matrimonio del primero con Sibil·la de Fortià y del segundo con Violant de Bar, mutuamente enemistadas ${ }^{42}$.

41 Sobre las continuas recriminaciones dirigidas por el monarca a los motivos antijudaicos que inspiraban a sus consejeros cfr. Idem, pp. 65-68.

${ }^{42}$ Sobre las discordias entre Pedro el Ceremonioso y el infante Juan, acentuadas desde sus respectivos matrimonios con Sibil·la de Fortià y Violant de Bar, y sostenidas por las enemistades de sendos círculos cortesanos, cfr. Jerónimo Zurita, Anales de la Corona de Aragón, edición de Ángel Canellas, Zaragoza, Institución Fernando el Católico, 1978, vol. IV, pp. 692-720. Cabe recordar que al heredar el trono, Juan I persiguió y procesó a su madrastra y a sus consejeros. Zurita sí recoge la noticia de las reivindicaciones 
El proceso de las hostias de Tardienta pone de manifiesto como las tesis rigoristas de Eimeric tenían buena acogida en la corte del infante en 1378. Por otra parte, la abierta enemistad entre Eimeric y el Ceremonioso había aumentado desde el Cisma de la Iglesia, pues el monarca desde el principio se declaró neutral en la contienda entre Roma y Aviñón, mientras Eimeric se demostró uno de los grandes defensores de la causa clementista. Quizás por esa razón, se acentuaran los lazos entre el dominico y el infante, pues en cuanto Juan subió al trono declaró la obediencia de sus reinos al pontificado aviñonés, levantó el destierro que pesaba sobre el dominico, y lo restituyó como inquisidor pontificio en la Corona de Aragón en 1387. Con todo ello se produjo la reapertura inmediata de la antigua causa contra los lulistas y, por extensión, la persecución de sus discípulos en el reino de Valencia. Las tesis radicales de Eimeric también eran escuchadas y asumidas en Valencia, al menos por el obispo, Jaume d'Aragó, quien ya en 1386 puso de nuevo en circulación la bula de Gregorio XI contra los lulistas, ordenando su plena observancia en la diócesis.

Tal y como había ocurrido tiempo atrás, las reiniciadas acciones de Eimeric acabaron con las simpatías que hasta entonces le había profesado Juan I: el 5 de junio de 1388 el monarca escribía al obispo de Valencia anulando todas las órdenes que anteriormente había dado contra las obras de Llull y las enseñanzas de sus seguidores. Días después, el propio rey escribió a Clemente VII para que designara un tribunal catalán que volviera a examinar las obras de Llull, pues habían sido declaradas heréticas por gentes que desconocían el idioma. Por otra parte, a principios de 1389 nuevos atropellos sobre los habitantes de la ciudad y reino, desencadenaron la interposición de un pleito del síndico de Valencia contra Eimeric ante el ordinario, aprovechando la presencia en la ciudad de Pedro de Luna, cardenal legado de Clemente VII en España ${ }^{43}$. El proceso fue apoyado por Juan I y terminó con la deposición de Eimeric como inquisidor del reino de Valencia, aunque siguió ejerciendo el cargo en el resto de la Corona de Aragón, motivo por el que Valencia en adelante contaría con un inquisidor propio, desgajado de la antigua jurisdicción única.

El éxito obtenido sirvió para que el gobierno municipal de Valencia, el de Barcelona y el propio Juan I, intentaran de nuevo que el papa aviñonés designase una comisión catalana para juzgar la obra de Llull, aunque el extraordinario peso con el que contaba la intransigente postura de Eimeric volvió a impedirlo. Tampoco Jaume d'Aragó, obispo de Valencia, ni Jofré Boïl, prelado y procurador real en la corte aviñosesa, apoyaron la propuesta, demostrando su sintonía con las tesis del dominico ${ }^{44}$. El asunto hacía patente una vez más la abierta diferencia de opiniones y posturas en el seno de la misma ciudad de Valencia. Por una parte, los jurados defendían la causa lulista y procesaban a los síndicos que habían solicitado la expulsión de Carroça de Vilaragut de la corte y, simultáneamente, la ampliación de la judería de Valencia. Por

del marqués de Villena en las Cortes de Monzón (pp. 731-733), pero apenas incluye unas breves líneas para recordar que el 5 de agosto de 1391 fueron asaltadas la mayor parte de las juderías, incluyendo el apunte de que en Valencia se bautizaron once mil judíos (p. 751).

${ }^{43}$ Cfr. A. Ivars, "Los jurados de Valencia ...", pp. 77-78.

${ }^{44}$ Cfr. Idem, pp. 88-89. Los jurados escribieron una amarga carta a Jofré Boïl, desde 1397 cardenal de Santa Maria de Aquino, quejándose del apoyo que prestaba a favor del inquisidor en la causa abierta contra aquél por Valencia y le recordaban los servicios que sus antepasados y sus parientes actuales habían brindado y brindaban a la ciudad, cfr. AMV, Letres misives g3-5 fol. 59v-60 (6 octubre 1391). 
otra parte, el obispo, Jaume d'Aragó, hermano de Alfonso, marqués de Villena, coincidía con las tesis del inquisidor Nicolau Eimeric y, además, sostenía la expulsión de los malos consejeros de la corte de Juan I. Fue entonces cuando Juan I se desentendió de las tesis de Eimeric, expulsó a Carroça de la corte, y empezó a escuchar a nuevos consejeros, los cuales veían con malos ojos todas las actuaciones de los jurados de Valencia, que procesaron por traición a los primeros síndicos remitidos a las cortes y más tarde habrían de castigar a los asaltantes de la judería. El propio marqués de Villena encabezando a la mayor parte de los caballeros del reino de Valencia se opuso a los jurados y, al mismo tiempo, parecía simpatizar con quienes habían sido presos por el asalto. Y todo esto cuando la considerable ampliación topográfica de la misma había encontrado la abierta oposición del vecindario, del convento dominico, de la iglesia de san Juan del Hospital y de una parte de la oligarquía valenciana. Finalmente, Eimeric fue destituido del cargo de inquisidor de la Corona de Aragón, desterrado y declarado enemigo de la real persona en 1392, al no querer retractarse de unas acusaciones proferidas desde el púlpito de la catedral de Lleida ${ }^{45}$.

\section{AMENAZAS DE GUERRA Y CONFLICTIVIDAD INTERNA}

La suspensión de las cortes en diciembre de 1389 se había producido con el pretexto de atajar la invasión de tropas del conde de Armañac, pariente de Mata de Armañac, primera esposa de Juan I, quien alegaba ciertos derechos de sucesión sobre el reino de Mallorca y los condados del Rosellón y la Cerdaña. De modo que tropas gasconas e inglesas penetraron en tierras de la Corona y amenazaron Girona, contando con el apoyo del conde de Ampurias, si bien la rápida actuación militar permitió su expulsión el 10 de marzo de 1390, aunque las sesiones de cortes no se retomaron ${ }^{46}$. Lo cierto es que el 8 de febrero de 1390 ya se había recibido noticia de una primera gran victoria real a cargo de Bernat Cabrera, apoyado por Gilabert de Centelles y otros valencianos, aunque el ejército continuaba sus operaciones y, por tanto, se hacía necesario su abastecimiento.

Los dieciocho elegidos en representación del reino, cumpliendo lo aprobado en las cortes de Monzón, se reunieron en el monasterio de Valldigna y adoptaron un paquete de medidas para el socorro de Cataluña, las cuales trasladaron a los diputados del General (el obispo de Valencia, el maestre de la Orden de Montesa, el marqués de Villena, Pere de Vilaragut, Jaume Marrades y Pons de Malferit) y a los clavarios que ellos mismos habían escogido (el obispo de Segorbe, Berenguer Llançol y Nicolau Valldaura). Entre los acuerdos figuraban la captación urgente de recursos financieros, mediante la venta de censales, para pagar con presteza gentes de armas que acudieran a la defensa, pero probablemente también previeron la salida de granos del reino para aprovisionar al ejército y a las localidades bajo riesgo de asedio. Los dieciocho resolvieron realizar la recaudación del donativo del siguiente modo: un tercio

${ }^{45}$ Cfr. Eliseo Vidal Beltrán, La Valencia de Juan I ..., pp. 278-284. El documento ha sido publicado por Agustín Rubio en Epistolari ... doc. 87 (9 mayo 1392) pp. 236-238.

${ }^{46}$ Rafael Tasis i Marca, Pere el Cerimoniós i els seus fills, Barcelona, Edicions Vicens Vives, 1980, pp. 172-173. 
mediante compartiment $\mathrm{o}$ impuestos directos y dos tercios mediante generalitats o impuestos indirectos sobre el consumo, introduciendo por vez primera la venta de censales para solventar los problemas de liquidez mientras se hacían efectivas ambas recaudaciones ${ }^{47}$. Aquel mismo día se subvencionaron los gastos del viaje a un grupo de almogávares que partían hacia la zona de guerra, a razón de dos florines por combatiente ${ }^{48}$. Tres días después los capítulos elaborados para recabar fondos todavía no habían sido suscritos por el rey, y se decidía rogar al marqués de Villena que acudiera cuanto antes en auxilio de Cataluña. Al mismo tiempo se solicitaba a Xàtiva y a las villas del reino que remitieran la parte correspondiente al servicio real, tal y como se había estipulado. Mientras tanto los comisarios reales y los jurados inspeccionaban la judería para aplicar los nuevos límites de la clausura ${ }^{49}$.

La guerra había permitido al reino de Valencia liberarse -al menos momentáneamente- de la obligación de abastecer de vituallas a la capital, y el 25 de febrero de 1390 el brazo militar, el brazo eclesiástico, la ciudad de Xàtiva y las villas reales habían solicitado abiertamente la revocación de "les inhibicions", mediante las cuales se vetaba la salida de vituallas del reino y, a la vez, garantizaban el abastecimiento de Valencia. Desde las cortes de 1371 Pedro el Ceremonioso había suscrito unos capítulos con el brazo real en los que se reservaba para él mismo, o al baile general del reino en su nombre, la capacidad de exportar productos prohibidos, negando explícitamente tal capacidad a los bailes de las villas reales o de los lugares pertenecientes a señores laicos o eclesiásticos ${ }^{50}$. Como esas inhibiciones eran consideradas por la capital "cosa fort cara e quasi la salut de la dita ciutat e encara del regne", el consell envío emisarios a la corte para evitar la suspensión de la prohibición de exportar vituallas $^{51}$. Al frente de aquellas reivindicaciones contrarias a la centralidad capitalina se encontraba otra vez Alfonso, marqués de Villena, acompañado de Berenguer

47 Sobre los diputados y clavarios cfr. M ${ }^{\text {a }}$ Rosa Muñoz Pomer, Orígenes de la Generalitat Valenciana, Valencia, Generalitat, 1987, pp. 121-122 y nota 249. Sobre la recaudación y la introducción de la financiación vía censal cfr. Juan Vicente García Marsilla, Vivir a crédito en la Valencia medieval. De los orígenes del sistema censal al endeudamiento del municipio, Valencia, Universitat, 2002, pp. 298-299.

48 AMV, Manuals de consells A-19, fol. 101v-102 (8 febrero 1390). Los jurados y el gobernador pasarían revista a la compañía antes de partir y de pagar la subvención, la cual fue costeada por la hacienda municipal, pero habría de cargarse a los gastos del general. Otro grupo de veinticinco almogávares voluntarios recibieron idéntica ayuda para realizar el viaje el 19 de febrero, fecha en la que el jurado Joan Fabra, habitador de Valencia, solicitaba y obtenía licencia del consell para abandonar sus funciones y servir al rey en Cataluña, recibiendo cien florines de subvención, cfr. fol. 108. El total de almogávares subvencionados ascendió a ciento veinte, cfr. AMV, Manuals d'albarans de claveria comuna I-18, fol. $25 \mathrm{v}$.

49 AMV, Manuals de consells A-19, fol. 103v-104 (11 febrero 1390). Sobre la presentación y aceptación del plan de actuación sobre la judería, "crescuda e arrodonida", y la comprobación de la mezcolanza de domicilios cristianos y judíos, fol. 107v (19 febrero 1390).

${ }^{50}$ Cfr. Furs de València, capítulos de 26 de abril de 1371, p. 313.

${ }^{51}$ AMV, Manuals de consells A-19, fol. 110 (25 febrero 1390). El 14 de marzo el consell ordenaba que se fiscalizasen las licencias de exportación, concedidas meses atrás con el único propósito de abastecer al ejército de Cataluña, cfr. fol. 112v. 
March, maestre de la Orden militar de santa María de Montesa, la ciudad de Xàtiva, y las villas de Alzira y Morvedre, aunque pronto se añadieron muchas más ${ }^{52}$.

Sin que pareciese tener relación con aquel asunto, el 8 de abril de 1390, el consell ordenó el reconocimiento de las armas de cada vecino para comprobar el estado de la milicia ciudadana y, de inmediato, se notificaba que Carroça de Vilaragut, señora de Corbera, había tomado prendas sobre los ganados de la ciudad que pastaban en Cullera, apresando a algunos vecinos de la localidad, término de Valencia, razón por la que se convocó en armas -con repique de campanas, exhibición de la señera, tambores y trompetas- a toda la población ${ }^{53}$. Un año después, el 6 de mayo de 1391, tras superarse de buenas maneras aquel incidente se procedía a redactar la normativa que regiría la caballería ciudadana ${ }^{54}$. Las intrigas de la corte y los tejemanejes de los consejeros reales, la actitud recalcitrante de los primeros síndicos enviados a las cortes de Monzón, los problemas derivados para hacer valer los derechos jurisdiccionales o aemprius de la ciudad sobre el territorio y la organización de una liga pluriestamental de intereses, que unía al brazo eclesiástico, al nobiliario y a las villas reales contra la capital, sin duda inspiraron la reacción preventiva y militar del consell. Pero todavía había más, porque el 18 de mayo de 1390 el gobierno ciudadano encargó la redacción de una original obra, de carácter institucional, que recibiría en nombre de "Libro del Bien y del Mal", una memoria escrita y viva para el archivo de la ciudad donde se consignarían dos listas de nombres, contemplando por una parte los de las personas y los de las comunidades que habían prestado buenos servicios a la ciudad y, por otra, una relación idéntica en la que se anotaría a los que con sus malas acciones la habían perjudicado, porque "esdevenir es pot, e ja es esdevengut, segons dehien per oblit, que alcuns de fer mal havien haudes remuneracions, e altres en contrari, ço que era gran perversió". Es probable que el texto nunca llegara a redactarse, dada la renovación anual mediante sistema sorteado de todas las magistraturas, lo que impedía no ya conservar sino calificar de tal modo las acciones de gobierno de sus predecesores, de los más destacados personajes de la ciudad o de las villas del reino ${ }^{55}$.

${ }^{52}$ Cfr. el documento de procuración suscrito por todos ellos, y en conjunto, en favor de Pere Llop, notario y síndico de Morvedre, con el fin de que los representase ante cualquier pleito, APPV, Notal de Joan de Sentfeliu 51 fol. 3-4 (12 marzo 1390).

53 El gobernador Roger de Montcada impidió ejecutar aquella convocatoria, presentándose en la sala del consell, para hacer constar el principio de un pleito bajo su jurisdicción; y que Carroça se había comprometido a liberar a los presos y a poner a disposición de la ciudad al escudero que perpetró aquellos actos, así como el compromiso de pagar los posibles daños provocados. Al día siguiente se presentaban en la sala los cautivos liberados y Ferran Ximènez alias Galceran de Riu-sec se comprometía a hacerse cargo de todos los gastos, pero como no se halló al culpable del secuestro el consell ordenó el registro de Corbera, cfr. AMV, Manual de consells A-19 fol. 121v-123 (8 abril 1390) y fol.123v-124v (15 abril 1390).

${ }^{54}$ Cfr. AMV, Manual de consells A-19 fol. 218-219v (6 mayo 1390).

55 Cfr. Josef Teixidor, Antiguedades de Valencia, tomo II, pp. 379-381. El 16 de julio de 1390 todavía no se no había comenzado a redactar la obra aunque el consell ratificaba idéntica voluntad, indicando que "a I cap sien escrites aixi singulars persones com universitats, faents bon servis e bones obres a la cosa pública, e en altre cap les faents o tractants lo contrari, e los dits serviis e obres de cascuns a certificació dels presents e memòria dels esdevenidors", cfr. AMV, Manuals de consells A-19 fol. 135 (18 mayo 1390) y fol. 155v (16 julio 1390). 
El 4 de junio 1390 se recibían las quejas de los vecinos de la Exerea y del convento de dominicos por los perjuicios que ocasionaba la clausura de la judería, y también se dejaba constancia del enfrentamiento de Valencia contra el reino ${ }^{56}$. El 9 de julio se iniciaba de nuevo la inspección para la reforma del plan de cierre de la judería en atención a las quejas recibidas, comisionándose a mosén Francisco de Aranda para tal fin, mientras se renovaba la posición común contra la vigencia de la prohibición de exportar vituallas, que contrariaba la obligación foral de abastecer la capital, sin duda a un precio menor en un mercado cautivo y jurídicamente garantizado ${ }^{57}$.

Al final del verano el consell, alegando la persistencia de la amenaza de guerra con Francia o con Armañac, y los rumores de ataque inminente desde Granada, pero también porque "molts de cascuns dels braços d'aquest regne dehien e comminaven, $e$ encara endreçaven, petigar o prejudicar en ses llibertats a la dita ciutat contra furs e privilegis", en lo referente al quebrantamiento de la prohibición de exportar vituallas, se adoptaron medidas coactivas, convocando a los cien hombres a caballo de la milicia según permitía a Valencia un antiguo privilegio hasta entonces nunca ejecutado. Sólo entonces se procedió a capitular las normas que regirían su funcionamiento "no solament per les dites rumors de guerres, mas encara per altres afers e servei de la dita ciutat, e per defendre e mantindre furs e privilegis e llibertats d'aquell, segons forma del dit fur e privilegi a servei de nostre senyor Déu e del senyor rei, e a bé e honor de la cosa pública dessús dita" ${ }^{58}$. En realidad, a finales de septiembre ya se había enrolado y pagado por adelantado el salario de la mayor parte de aquella caballería ciudadana, tal y como comprobaremos. También se organizó la milicia de infantería en decenas y cincuentenas, y se ordenó colocar cadenas en las esquinas y en las calles, renovando las que estuvieran deterioradas o en mal estado, e instalando otras nuevas en lugares estratégicos, con el propósito de evitar las cabalgadas y correrías de los desatados bandos. La correlación, entre el quebrantamiento de los derechos de la ciudad sobre el reino y el despertar de la violencia banderiza de algunos caballeros, era evidente. De este modo, quedaba manifiesto que el deseo de aplicar el antiguo privilegio - que permitía organizar una milicia ciudadana a caballo para defender los fueros, privilegios y libertades- no tenía tanta relación con la defensa ante posibles, lejanas e inciertas agresiones, externas al reino, como con el deseo de hacer respetar "les inhibicions" al brazo militar y a las villas reales.

\section{EL CHOQUE ENTRE LA CIUDAD Y EL REINO}

El 16 de noviembre de 1390 un importante grupo de villas reales se habían sumado a la iniciativa reivindicativa del marqués de Villena, compartida también por la orden

${ }^{56}$ AMV, Manuals de consells A-19, fol. 145v-146v (4 junio 1390). En la reunión se daba noticia de que había habido "debat o altercació gran devant lo senyor rey" entre la ciudad de Valencia y los brazos militar y eclesiástico del reino, más Xàtiva y las villas reales, por razón de la prohibición de exportar vituallas. El consell formó una comisión de prohombres para consensuar a las partes y remitió emisarios a las villas para convencerlas, sin éxito, de lo provechoso de su postura.

${ }^{57}$ AMV, Manuals de consells A-19, fol. 151v-152 (9 julio 1390).

${ }_{58}$ AMV, Manuals de consells A-19, fol. 161-162v (6 septiembre 1390). 
de Montesa, por Xàtiva, Alzira, Morvedre. Borriana, Morella, Castielfabib, Xixona, Alpont, Ademuç, Ontinyent y Biar, todas las cuales hicieron parte con el brazo eclesiástico y el brazo militar. El grupo fue requerido por la ciudad de Valencia para que no se reuniese con el propósito de tratar una actuación conjunta y contraria a los fueros y privilegios del reino, aduciendo que podría reportarles graves perjuicios. Según la notificación notarial el objetivo de los conjurados era derogar los fueros aprobados en las cortes de Fraga y de Monzón, si bien la respuesta colectiva aducida por aquéllos insistía en que su reunión estaba autorizada con licencia de Juan I, y que no pretendían derogar los fueros sino todo lo contrario, es decir, defender lo acordado en Fraga y Monzón, así como los intereses de los tres brazos del reino, con el fin de lograr la perfección de la cosa pública. Finalmente, los aliados dejaban constancia de que aquella decisión conjunta de protesta no estaba respaldada por los síndicos de Morvedre, aunque sus deliberaciones se habían realizado en la sala del consell de aquella villa. No obstante, interrogados por el notario en tal sentido los mismos delegados de Morvedre suscribieron voluntariamente la moción contra Valencia ${ }^{59}$.

Fue entonces cuando el consell comisionó a un grupo de prohombres para tomar contacto con los reivindicativos representantes del brazo eclesiástico, del militar y de las villas reales, encabezadas por Xàtiva y Morvedre, y en especial con algunos "generosos" del brazo militar residentes en Valencia, los cuales tenían posibilitado el acceso a sus magistraturas de gobierno. Según se hacía constar los brazos "mal informats" impugnaban las inhibiciones, así como otros asuntos no explicitados pero -eso sí- pactados en las anteriores cortes de Monzón ${ }^{60}$. El conflicto con el reino creció de forma imparable, polarizado en Morvedre, porque aquélla era una villa reducida a la obediencia y jurisdicción directa de Valencia tras la Guerra de los Dos Pedros. Con el pretexto de que Morvedre se negaba a pagar la parte correspondiente de lo que la capital había adelantado a Juan I para hacer frente a las tropas invasoras en Cataluña (quinientos de los cinco mil florines, más cuatro libras y quince sueldos por gastos derivados del envío de la remesa monetaria) se convocó a la milicia ciudadana. El verguero y el notario remitidos a Morvedre para tomar cauciones por la insubordinación habían sido rechazados en la villa, desatando la convocatoria de hueste y cabalgada en Valencia para ejercer allí la jurisdicción capitalina. El consell requirió la presencia de la población, a pie y a caballo con pan para diez días, haciendo especial mención para que ricoshombres, caballeros y generosos domiciliados o habitantes en Valencia, y aquéllos que habían sido electos en las magistraturas, siguieran a la señera -según rezaban sus obligaciones- y defendieran los fueros y privilegios, siendo convocados mediante un pregón específico dirigido a ellos ${ }^{61}$. Por su parte, la villa planteó pleito contra la capital en la gobernación con el fin de eliminar la prohibición de exportar vituallas. Es decir, los brazos eclesiástico y militar, más los síndicos de algunas villas reales, con Xàtiva y Morvedre a la cabeza, y con casi todo el reino detrás, habían formado una auténtica liga de intereses contra Valencia impugnando las inhibiciones, pues todos los conjurados se habían coordinado para negarse a respetar las medidas aprobadas en las cortes de Monzón, así como la organización militar

\footnotetext{
${ }^{59}$ Cfr. APPV, Notal de Joan de Sentfeliu 51 fol. 25v-33 (16 noviembre 1390).

${ }^{60}$ AMV, Manuals de consells A-19, fol. 175-175v (15 noviembre 1390).

${ }^{61}$ AMV, Manuals de consells A-19, fol. 163v-164v (14 septiembre 1390).
} 
prevista en caso de guerra, posiblemente referida al reparto de gastos derivados de la ayuda remitida a Cataluña ${ }^{62}$. ¿Había capital judío implicado en el arrendamiento o recaudación de las generalidades aprobadas para financiar la guerra?. Cabe recordar que Jafudà Alatzar fue comisionado para recaudar el donativo votado en las cortes de 1367 y en las de 1371, el cual ejerció de clavario de la ciudad de Valencia desde mediados de la centuria hasta su muerte en 1377, y que estuvo implicado en todas las operaciones financieras de la Corona y de la tesorería real, además de mantener una cartera de acreedores particulares ${ }^{63}$.

Días después, y para quitar hierro al conflicto la capital hizo marcha atrás, buscando actos de conciliación que limaran las asperezas. Por una parte, revocó el antiguo estatuto que impedía al justicia poner en manos de la jurisdicción eclesiástica a los criminales tonsurados. La coyuntura condicionaba la inusual medida con el propósito municipal de atraerse las simpatías del brazo eclesiástico, al reconocer su independencia jurisdiccional, sin tener en cuenta los graves conflictos que aquello había causado en el pasado y que, aún, tendría que padecer en el futuro. Por otro lado, cinco vecinos de Cullera, presos por rebeldía e inobediencia durante una temporada y condenados con pena pecuniaria y privación de oficios ¿por su actitud ante las inhibiciones? fueron perdonados sin mayores explicaciones, aunque se preveían castigos mayores en caso de reincidencia ${ }^{64}$. Pero esta doble actitud benevolente no sirvió de nada y los rebeldes volvieron a reunirse en Moncada, lugar de señorío ajeno por tanto a la autoridad de Valencia, desde donde decidieron enviar emisarios a Juan I para rectificar los molestos capítulos de cortes aprobados en Fraga y Monzón ${ }^{65}$. En aquellas asambleas se había regulado la recaudación del donativo otorgado al monarca mediante un compartiment o fraccionamiento de una cifra total entre los estados de la Corona de Aragón, el cual no fue aceptado entonces como justo o equitativo. Además, allí se había atribuido la competencia recaudatoria en el reino de Valencia a un ciudadano de la capital -Jaume Romeu, entonces diputado del general, quien en 1389 sería procesado por traición- engendrando antaño las protestas de Xàtiva y otras villas reales por los perjuicios que de ello podrían derivarse ${ }^{66}$. El 11 de febrero de 1391, el consell se ratificaba para poner en vigor y alerta a la caballería ciudadana $\mathrm{y}$, en esa misma reunión, ordenaba a Vido de Causach, mestre e botiguer d'arneses de tota guisa, vecino de Valencia, que fabricara y comprara armas por valor de quinientos florines ${ }^{67}$. Entonces se apelaba al rey sobre los límites otorgados para el cierre de la judería ${ }^{68}$.

${ }^{62}$ AMV, Manuals de consells A-19, fol. 174v-175 (15 noviembre 1390). El 18 de julio de 1390 los diputados del General previeron la subasta de las generalidades con tal objeto, cfr. APPV, Notal de Joan de Sentfeliu 51, fol. 9-9v.

63 Jaume Riera i Sans, "Jafudà Alatzar, jueu de València (segle XIV)", Revista d'Història Medieval 4 (1993), pp. 82-83.

${ }^{64}$ AMV, Manuals de consells A-19, fol. 176v-177 (18 noviembre 1390).

${ }^{65}$ AMV, Manuals de consells A-19, fol. 179 (29 noviembre 1390).

${ }^{66}$ Cfr. Capítulos de las cortes, iniciadas en Monzón en junio de 1383 y concluidas en Fraga en julio de 1384, en Furs de València, p. 349.

${ }^{67}$ AMV, Manuals de consells A-19, fol. 195-195v (11 febrero 1391).

68 AMV, Manuals de consells A-19, fol. 197v (20 febrero 1391). El consell ordenaba a su síndico que continuase la presentación de la apelación dirigida al rey contra los lindes dados a la judería. Más 
En la renovada propuesta de corregir sus límites, el 8 de abril de 1391, los vecinos de la Exerea proponían al consell la apertura de una calle nueva que permitiera unir la Plaza de la Figuera con el Portal de la Exerea para evitar el tránsito a través de la judería, iniciándose la estimación visual de los costos de un proyecto que pretendía prolongar el adzucat o callejón del Milagro hasta la calle Trinquete de Caballeros. Después, se trató de la puesta en vigor del privilegio real para organizar la milicia a caballo, comisionándose a un numeroso grupo de ciudadanos y menestrales para que estudiaran los capítulos que la regirían ${ }^{69}$. Y a finales de mes el proceso de traición iniciado ante la gobernación contra los primeros síndicos enviados a las cortes se había trasladado desde Valencia a Alzira, y después hasta Castellón, a instancias de los escritos presentados por los acusados, pues alegaban -y se les había reconocido en el tribunal de la gobernación- la posible malquerencia de esas sedes. Fue entonces cuando llegó al consell la noticia de que los procesados, contraviniendo el procedimiento, habían abandonado la última localidad y se dirigían hacia Valencia, lo que contrariaba la voluntad municipal y presuponía inminentes alteraciones del orden público. Por este motivo se ordenaba a Jaume Marrades, justicia criminal, que estuviese apercibido con su lugarteniente y guardias, para evitar posibles bandos y prender a los procesados por desobediencia ${ }^{70}$.

El 13 de mayo se elegían nuevos jurados y el 14 de junio se presentaba la queja de los mayorales del oficio de sastres por los perjuicios que recibían en su actividad profesional de los judíos, los cuales saliéndose de los límites de su barrio invadían las zonas colindantes. Los sastres aducían que los judíos contaban con el apoyo del baile y de "alcuns grans hòmens" ¿los que habían propuesto en las cortes la ampliación de la judería y estaban siendo procesados por traición? ¿Los caballeros reticentes a aceptar las directrices de los jurados?. Por ello se decidió que los abogados del municipio analizaran la pronunciada sentencia sobre la última limitación de la judería, pues a pesar del acuerdo alcanzado para abrir la nueva calle que permitiera a los cristianos evitar el barrio - cuando se dirigieran al centro de la ciudad o a la Puerta del Marnada se había aplicado ${ }^{71}$.

Para complicar un poco más la situación y alterar la escasa tranquilidad de ánimo en el turbio ambiente ciudadano, Nicolau Eimeric, inquisidor contra la herética pravedad, lanzaba sus anatemas e iniciaba algunos procesos de herejía contra ciertos vecinos de Valencia y habitantes del reino en aquel mismo mes de mayo ${ }^{72}$. No mucho tiempo después, Eimeric llegaría a plantear públicamente que Valencia estaba llena de herejes; que podían contarse más de quinientos; y que todo en la ciudad estaba guiado por el mismo diablo. ¿Todos aquellos herejes eran reconocidos seguidores de

tarde, el 26 de abril, se recibían las quejas de Llorenç Desgraus, presbítero, porque junto a otros vecinos habían comprado solares de antiguas casas y, entre todos, habían construido una placeta, que ahora se había incorporado a la clausura, en grave perjuicio de su inversión, cfr. fol. 212v-213.

${ }^{69}$ AMV, Manuals de consells A-19, fol. 208v y 210 (8 abril 1391). Al menos nueve de los dieciocho comisionados, ciudadanos y menestrales, formaron parte de la misma caballería: Guillem Iborra (barbero), Bernat Sauret, Vicent Nadal, Miquel Cardona, Guillem Çaera (abogado), Leonard Marrades, Nicolau Valldaura, Garcia del Porto, y Miquel Cardona, hijo.

${ }^{70}$ AMV, Manuals de consells A-19, fol. 209-210 (8 abril 1391) y fol. 214-214v (27 abril 1391).

71 AMV, Manuals de consells A-19, fol. 230v-231 (14 junio 1391).

72 AMV, Letres misives g3-5 fol. 5v-6 (24 mayo 1391). 
las tesis de Ramon Llull o podría deducirse que eran considerados tales por sus comportamientos y actuaciones institucionales? ¿Respecto a la prevista ampliación de la judería? El 4 de julio de 1391 el infante Martín presentaba ante el consell una carta de Juan I en la que el rey solicitaba consejo, préstamo y dones de la ciudad de Valencia para la organización de la armada que pacificaría Sicilia ${ }^{73}$. Cinco días después se producía el asalto de la judería. Un mes más tarde los jurados, muy contrariados, se hacían eco de que Carroça de Vilaragut había expresado su deseo de retornar a la corte de Juan I cuando lo tenía expesamente vetado ${ }^{74}$.

\section{LA MILICIA MONTADA Y EL ORDEN PÚBLICO}

Para hacer frente a la resistencia ofrecida por el reino contra la aplicación de los derechos jurisdiccionales de la capital, el 6 de mayo de 1391, el consell aprobaba los capítulos de organización de una tropa de cien hombres, setenta de caballería pesada y treinta de caballería ligera, según la previsión contemplada en el privilegio real otorgado el 23 de julio de 1376. Diez hombres de paraje, treinta ciudadanos de la mano mayor, otros tantos de la mano media y de la menor, formarían una milicia montada que pasaría revista dos veces al año, en san Jorge y en san Dioniso, con la misión de acompañar a la bandera o de acudir a la playa en caso de ataque marítimo, siempre bajo las órdenes del justicia criminal y de los jurados, a cambio de recibir veinticinco o veinte libras anuales según el caso ${ }^{75}$. Aquella medida era consecuencia efectiva de la decisión de las segundas cortes generales de Monzón en 1389, asumidas por el consell como insoslayables el 6 de mayo de $1391^{76}$.

La novedad de esta decisión radicaba no sólo en la primera organización de la fuerza quince años después de su creación, sino en la previsión de un pago específico, anual y adelantado, que habría de suponer una fuerte carga anual para la hacienda municipal ${ }^{77}$. Ni antes ni después de 1391 se mantuvo asalariada aquella caballería. La

73 AMV, Manuals de consells A-19, fol. 239v-240v (4 julio 1391). La carta original de Juan I estaba datada en Zaragoza el 24 de mayo de 1391.

${ }^{74}$ AMV, Letres misives g3-5 fol. 48-49v (29 agosto 1391).

75 AMV, Manuals de consells A-19, fol. 218-219v (6 mayo 1391). Este centenar de caballería se sumaba a otro centenar de infantería o de ballesteros que por privilegio de Pedro el Ceremonioso ( 3 de junio de 1365) la ciudad podía convocar para defender los fueros y privilegios. Cfr. Francesc Sevillano Colom, El Centenar de la Ploma de la ciutat de València, 2365-1711, Barcelona, Rafael Dalmau editor, 1966, en especial pp. 20-24. También Luis Querol y Roso, Las milicias valencianas del siglo XIII al XV, Castellón, Sociedad Castellonense de Cultura, 1935, doc. 11, de 23 de julio de 1376, que concede como fuero de las cortes de Monzón la primera creación de la fuerza de caballería.

${ }^{76}$ AMV. Manuals d'albarans de claveria comuna I-19, fol. 3-40v. A lo largo de distintos pagos se libraron las cantidades previstas hasta un total de veinte caballos alforrados y cincuenta y siete armados.

77 Sobre la decisión adoptada en las segundas cortes generales de Monzón, cfr. AMV, Manuals de consells A-19, fol. 210-210v (8 abril 1391). La cifra anual prevista ascendería a 1.350 libras, es decir $2.454^{\prime} 54$ florines de oro o 27.000 sueldos ( 1 florín $=11$ sueldos $=0 ` 55$ libras). Conviene indicar que en la nómina figuraban al menos tres de los cuatro síndicos enviados a Monzón en sustitución de los que fueron procesados por traición (Guillem Çaera, Nicolau Valldaura y Jaume Marrades), y que al menos nueve de los dieciocho designados por los jurados para prever su organización también figuraron entre sus integrantes, tal y como se indicó en la nota 69. 
costumbre demostraba que cuando se necesitaba recurrir a las armas para hacer valer las decisiones del consell sólo se asoldaba a un contingente vecinal por un tiempo determinado. Hasta esa fecha el servicio militar había sido cumplimentado por los vecinos convocados en armas, que a pie o a caballo, y cuando era necesario, eran enrolados con un salario prefijado para cumplir el servicio.

Sin embargo, en los registros de la clavería municipal se han conservado los pagos ejecutados a esa caballería, entre el 1 de junio de 1391 y el 4 de mayo de 1392, lo que contrasta con la ausencia de anotaciones similares en momentos anteriores o posteriores. Los libramientos afectan nominalmente a veinte titulares de los treinta jinetes de caballería ligera y a cincuenta y siete de los setenta de caballería pesada, lo que hacen un total de setenta y siete enrolados, de los cuales al menos sesenta estuvieron asalariados antes del asalto a la judería. La mayoría de ellos son vecinos, algunos ciudadanos notables y muy pocos caballeros (Pere Despuig, Joan Vives, Alfons Roís de Corella y Pere Roís d'Isverre), que evidentemente no sucumbieron al atractivo de tan sustanciosa paga, probablemente por su reticencia a participar en las decisiones municipales que contrariaban sus propios intereses. Conviene recordar su participación en la conjura para anular la prohibición de exportación de vituallas fuera del reino. De hecho, la organización de una nueva fuerza cívica nacía de la propia insubordinación del estamento militar, eclesiástico y real contra la hegemonía de la capital. ¿Para que servía esta caballería si la ciudad podía convocar y había convocado en armas a toda la población? ¿Su existencia podría estar relacionada con el mantenimiento del orden público dentro de la ciudad? ¿Su creación respondería a las imperativas necesidades de defensa respecto a agresiones externas?

Tabla 1. Relación de titulares de la caballería montada

\begin{tabular}{|l|l|l|l|}
\hline Fecha & Titular & Caballos & Manuals d'albarans \\
\hline 1391 junio 1 & Francesc Alquècer & $\begin{array}{c}\text { Cavalls alforrats } \\
\text { (caballería ligera) }\end{array}$ & I-19, fol. 3 \\
\hline & Jaume Roíç & & \\
\hline & Bernat Guitard & & \\
\hline & Bernat Canyelles & & \\
\hline & Joan d'Aragó & & \\
\hline & Antoni Piquer & & \\
\hline & Guillem Iborra & & \\
\hline & Jaume Carrrasquer & & I-19 fol. 3v-4 \\
\hline & Pere Oliver & & \\
\hline 1391 junio 5 & Bertomeu d'Almenar & & Cavalls alforrats \\
\hline
\end{tabular}




\begin{tabular}{|c|c|c|c|}
\hline & Lluís Frexinet & & \\
\hline & Joan Eximènez & & \\
\hline & Simon Femades & & \\
\hline & Joan Roíç & & \\
\hline & Joan Jordi & & \\
\hline & Francesc d'Atzuara & & \\
\hline & Pere Colomer & & \\
\hline & Miquel Péreç & & \\
\hline & Ferrando Lorenç & & \\
\hline \multirow[t]{10}{*}{1391 junio 16} & Jaume Soler & $\begin{array}{l}\text { Cavalls armats } \\
\text { (caballería pesada) }\end{array}$ & I-19 fol. $5 v-6$ \\
\hline & $\begin{array}{l}\text { Galceran } \\
\text { Cesfàbregues }\end{array}$ & & \\
\hline & Jaume Sala & & \\
\hline & Bernat Sauret & & \\
\hline & Berenguer Cardona & & \\
\hline & Jaume Bonet & & \\
\hline & Domingo de Sayes & & \\
\hline & Ramon Palaya & & \\
\hline & Joan Vilarnau & & \\
\hline & Salvador Amigó & & \\
\hline \multirow[t]{10}{*}{1391 junio 28} & Pere Solanes & Cavalls armats & I-19 fol. 7 \\
\hline & Vicent Nadal & & \\
\hline & Lluís d'Agramunt & & \\
\hline & $\begin{array}{l}\text { Miquel Cardona, pus } \\
\text { jove }\end{array}$ & & \\
\hline & Arnau Olives & & \\
\hline & $\begin{array}{l}\text { Mestre Vido de } \\
\text { Causach }\end{array}$ & & \\
\hline & Guillem de Rocafort & & \\
\hline & Bernat Aguells & & \\
\hline & Ramon Gostantí & & \\
\hline & Lluís Galvany & & \\
\hline 1391 julio 7 & Micer Guillem Çaera & Cavalls armats & I- 19 fol. $8 v-9$ \\
\hline
\end{tabular}




\begin{tabular}{|c|c|c|c|}
\hline & Micer Pere Català & & \\
\hline & Bernat Abelló & & \\
\hline & Guillem de Manresa & & \\
\hline & Guillem Estrany & & \\
\hline & Bernat de Celma & & \\
\hline & Martí de Sayes & & \\
\hline & Bertomeu Maçalio & & \\
\hline & Francesc Cosquella & & \\
\hline & Antoni Forès & & \\
\hline \multirow[t]{10}{*}{1391 agosto 17} & Leonard Marrades & Cavalls armats & I-19 fol. $12 v-13$ \\
\hline & Joan Cabanyelles & & \\
\hline & Francesc d'Arqués & & \\
\hline & Lluís de Manresa & & \\
\hline & Andreu Savila & & \\
\hline & Pere Donat & & \\
\hline & Arnau Alegre & & \\
\hline & Galceran Clavell & & \\
\hline & Pere Desplà & & \\
\hline & Antoni Atzuara & & \\
\hline \multirow[t]{10}{*}{1391 septiembre 16} & $\begin{array}{l}\text { Mossèn Pere } \\
\text { Despuig, generós }\end{array}$ & Cavalls armats & $\mathrm{I}-19$ fol. $15 \mathrm{v}$ \\
\hline & Joan Vives, generós & & \\
\hline & Jaume Marrades & & \\
\hline & Nicolau Valldaura & & \\
\hline & Joan de Valleriola & & \\
\hline & Miquel Cardona & & \\
\hline & Miquel de Novals & & \\
\hline & Antoni Mir & & \\
\hline & Garcia Sànxeç & & \\
\hline & Simon Caldes & & \\
\hline \multirow[t]{2}{*}{1392 mayo 4} & Francesc d'Aguilar & Cavalls armats & $\mathrm{I}-19$ fol. $40 \mathrm{v}$ \\
\hline & Bertomeu Miró & & \\
\hline
\end{tabular}




\begin{tabular}{|l|l|l|l|}
\hline & Alfons Roís de Corella & & \\
\hline & Pere Roís d'Isverre & & \\
\hline & Pere Vinyech & & \\
\hline Garcia del Porto & & \\
\hline & Joan de Requena & & \\
\hline
\end{tabular}

Pese a los argumentos que insistían en que su creación estaba relacionada con los rumores de guerra en Cataluña o con los procedentes de Granada, esta pequeña fuerza carecería de valor si hubiera de enfrentarse a un ejército invasor. Por otro lado, el orden público se mantenía con un cuerpo asalariado por el justicia y su lugarteniente, todos renovados anualmente, que constaba de doce caporales o jefes de la guardia, acompañados por una compañía vecinal para rondar cada una de las doce parroquias. También podría considerarse que la organización de la milicia a caballo estuviera relacionada con los miedos a la propagación de los asaltos de las juderías, puesto que la cronología vendría a coincidir con la recepción de las noticias sobre los primeros ataques en Andalucía y, de hecho, la mayor parte de los seleccionados para esa tropa comenzaron a cobrar y prestar servicio el 1 de junio de 1391, con lo que su organización efectiva abre la posibilidad de considerar la presunción de posibles e imprevisibles contingencias y desórdenes. Sin embargo, lo único cierto que podemos deducir es que esta caballería montada y subvencionada estaba seleccionada por el grupo hegemónico en el gobierno municipal, el cual constituía la fuerza con aquellos titulares que tuvieran demostrada su confianza, excluyendo sin duda a todos los que habían hecho parte con el grupo de patricios procesados por traición o a los caballeros reticentes a observar la obligación de avituallar Valencia, que por entonces amenazaban el orden público.

Ahora bien, esta fuerza sí era especialmente útil para actuar contra los grupos armados que acompañaban a los bandos urbanos, capaz de frenar incluso las posibles violencias de los caballeros, como también para hacer respetar los fueros y privilegios, en especial los derechos jurisdiccionales de la capital sobre el territorio. Esta fuerza efectiva podía atemorizar e imponer el respeto a la ley con rapidez y contundencia, es decir, aplicar coactivamente el veto a las exportaciones sobre las villas y señoríos del reino, sometiendo a los insumisos en Cullera, Morvedre o, más tarde, Xelva.

No encontramos referencia a la acción de esta caballería en el inesperado asalto de la judería y, en cambio, sí comprobamos su movilización en el intento frustrado en asalto a morería al día siguiente. El 10 de julio se convocó a la milicia de infantería y de caballería según atesta el acta del consejo, de modo que esta fuerza bajo el mando del infante Martín evitó el ataque al barrio mudéjar de Valencia. También cabe recordar que en ambas jornadas se atestó una heterogénea participación social 
en los disturbios -grandes, medianos y pequeños- resultando presos en torno a diez hombres de paraje y setenta u ochenta del pueblo ${ }^{78}$.

Cuando aquel mismo día el consell dejaba constancia escrita de lo acaecido, para certificación presente y memoria futura, se indicó que semanas atrás los judíos y el propio Juan I habían solicitado protección a los jurados tras apercibirse de las nefastas noticias que procedían de Castilla. Esa llamada de atención hubo de producirse después del cuatro de junio pero entre las actas de la asamblea municipal no se atesta la adopción de precauciones ${ }^{79}$. En cambio sí se documentan otro tipo de incidentes. El 14 junio 1391 el consell prohibía jugar a la "pilota arruladiça" a los mayores de diez años en las calles, bajo pena de prisión y azotes públicos sin posibilidad de remisión o de composición pecuniaria ${ }^{80}$. Con ello trataba de evitar que adolescentes y jóvenes profirieran blasfemias e injurias contra Dios y los santos del paraíso, lo que atentaba contra el decoro cívico, estipulándose entonces como castigo disuasorio una punición durísima para aquel inocuo delito porque -según se argumentaba- también engendraba desórdenes ¿contra los judíos?. Conviene llamar la atención sobre la situación histórica de la denominada calle Trinquete de Caballeros, que desemboca en la calle de la Mar, linde de la judería ${ }^{81}$. Dos días más tarde el justicia criminal y su lugarteniente exponían en sesión ordinaria del consell que, a pesar del pregón realizado, "alcuns hòmens jovens de paratge e ciutadans de perversa condició" en menosprecio y escarnio de la ciudad, de sus autoridades y del vecindario, habían quebrantado la paz pública durante la noche formando una comitiva burlona que parodiaba una ejecución de justicia, con la aplicación simulada de azotes sobre uno de ellos, exhibido desnudo y montado sobre un asno, al mismo tiempo que con gritos hacían saber que su único delito era haber jugado a la pelota en las calles. La caterva juvenil además de reírse y regodearse de la amenazante ordenanza municipal, había proferido insultos y aporreado las puertas de los domicilios de destacados prohombres que participaban en el gobierno ciudadano, entre ellos los de los mismos jurados. Por ello, el lugarteniente del gobernador y el justicia avisaban de que la situación era peligrosa, pues tenían noticia de que los aludidos, y otros, estaban dispuestos a tomar las armas contra quienes les escarnecían con cánticos y motetes, amparados en la oscuridad, de modo que el consell se ratificó en la dura aplicación penal de la ordenanza para evitar ese tipo de desórdenes ${ }^{82}$.

${ }^{78}$ AMV, Manuals de consells A-19 fol. 242-245v (10 julio 1391); y Letres misives g3-5 fol. 20v-22v (14 julio 1391), carta dirigida a Ramon de Soler y Pere Marrades, embajadores en la corte donde se narran ambos acontecimientos, publicada por Josef Teixidor en Antiguedades de Valencia, en especial pp. 162-163, donde se indica "Mes avant ordenà lo consell que ls hòmens a cavall que la ciutat té ..." (fol. 21v). En otra carta de 24 de julio de 1391 se hace constar que el infante Martín había capturado a cien personas de diversa condición y que se habían iniciado los procesos correspondientes, pidiéndose que se castigase a los culpables sin excepción de estado y condición de las personas (fol. 248v-249v).

${ }_{79}$ No obstante, aparecen referenciadas en los registros contables de las obras municipales, cfr. $\mathrm{M}^{\mathrm{a}}$ Milagros Cárcel - José Trenchs, "Disposiciones urbanísticas ..." doc. 248 (27 junio 1391).

${ }^{80}$ Cfr. AMV, Manuals de consells A-19, fol. 232v-233 (14 junio 1391).

${ }^{81}$ La calle Trinquete Caballeros recibió anteriormente el nombre de Trinquet del Pavorde o Trinquet Nou de Sant Joan de l'Hospital, cfr. Manuel Carboneres, Nomenclator de las puertas, calles y plazas de Valencia, p. 94.

82 Cfr. AMV, Manuals de consells A-19, fol. 234-235 (16 junio 1391). Pese a la presunta intranscendencia de este asunto menor en materia de orden público, los jurados transmitieron el incidente 
La anécdota tenía como protagonista a un grupo de jóvenes, burlones y noctámbulos, pero de forma paradójica había gentes dispuestas a utilizar las armas contra ellos ¿sólo por el supuesto atentado contra el honor que habían sufrido al ser objeto de mofa o por qué además de la prohibición del juego de la pelota se enjuiciaba la acción de gobierno del consell, en la que podría incluirse la ampliación de la judería, la conservación de las inhibiciones o el pleito de traición contra algunos patricios?. A la semana siguiente comparecían en el consell tres caballeros, mosén Joan de Bellvís, mosén Aznar Pardo de la Casta y mosén Pelegrí de Montagut, con el fin de disculpar las acciones de algunos jóvenes, vástagos de algunas familias de hombres de paraje y de afamados ciudadanos -probablemente sus hijos o parientes-, los cuales habían sido presos por el justicia cuando por la noche vituperaban con locas palabras a reconocidos miembros de la comunidad. Los caballeros, dignamente, suplicaron el perdón e intercedieron por los presos, aduciendo que tanto el desconocimiento de la ordenanza como el insensato comportamiento juvenil, propio de la edad, había llevado a aquellos jóvenes "per solaç e per lascivia del jovent ... a peguejar e arlotejar". La solicitud fue escuchada por los próceres urbanos, dado el ascendiente que aquellos tres personajes tenían sobre la ciudad, decidiéndose finalmente su liberación sin castigo, aunque acompañada de una reprimenda verbal que tendrían encomendada el justicia y el gobernador para amedrentar tanto a los escandalosos presos como a aquéllos de sus acompañantes que habían logrado escapar de la ronda. Además, se ordenó repetir el pregón que vetaba el juego de la pelota por todos los rincones de Valencia ${ }^{83}$. Apenas dos semanas después, el 9 de julio de 1391, a mediodía, un nutrido grupo de jóvenes en grotesca y tumultuosa procesión -muy similar a la comitiva nocturna que se ha referido- se dirigió hacia la judería para atemorizar y escarnecer a sus moradores, dando pie al incidente que provocaría el asalto a la judería.

\section{8. ¿PREGUNTAS SIN RESPUESTA?}

¿Es posible descontextualizar el asalto de la judería de la inédita organización de la caballería, de la liga del reino contra la capital, del proceso a los patricios traidores, y de los bandos ciudadanos? ¿Los desordenes nocturnos protagonizados por los hijos de honorables caballeros sólo eran resultado de una francachela? Las circunstancias de la ciudad no sólo eran complejas sino muy conflictivas en distintos pero muy interconectados asuntos, lo que hubo de contribuir de algún modo al estallido de la violencia contra la minoría hebrea, aprovechando el viento contagioso que en esos momentos llegaba de poniente. La participación de hombres de paraje y de notables ciudadanos en el pogromo no era una anécdota trivial sino que aparecía completamente contextualizada, pese a que existieran existían motivos específicos para dejarse arrastrar por las pasiones de la chusma. En este sentido conviene traer a colación

a su representante en la corte, Pere Marrades, a la sazón botellero de Juan I, con el fin de que hiciera llegar la noticia a oídos de aquél, ya que después de aquello muchos hombres de paraje habían hecho causa común con los jóvenes e insultaban abiertamente a los jurados, cfr. AMV, Letres Misives g3-5, fol. 15-16 (15 junio 1391).

${ }^{83}$ Cfr. AMV, Manuals de consells A-19, fol.236-236v (23 junio 1391). 
un dato no confirmado: en el pleito de traición iniciado en la gobernación contra los cuatro primeros síndicos remitidos a las cortes de Monzón se alegó que uno de sus detonantes había sido la ampliación de los límites de la judería y las veinticinco casas nuevas que pretendían abrir los judíos ${ }^{84}$.

Tras el asalto llegó la calma y de inmediato la solución entrelazada y fluida de todos aquellos conflictos, lo que parece apuntar de nuevo su interconexión. El 19 de julio se imponía a rajatabla la confiscación de armas prohibidas que lucía sin reparos buena parte de la población ${ }^{85}$. El 19 agosto se intentaba una nueva concordia con quienes atacaban las inhibiciones, tratando de evitar rencores y también se ordenaba la persecución de vagabundos ociosos mediante la reactualización de las ordenanzas vigentes $^{86}$. En septiembre se modificaban los estatutos que impedían mantener ganados de carniceros en la huerta, aunque se aumentaba la vigilancia y capacidad de penalización entre los guardias de la huerta ${ }^{87}$. El 13 de octubre nobles y caballeros, por una parte, y la capital, por otro, habían enviado emisarios al rey para que fuesen atendidas respectivas peticiones en tema de las inhibiciones ${ }^{88}$. El primer día de diciembre el consell llegaba un acuerdo con el infante Martín: le prestaba las cantidades necesarias para armar su flota y a cambio tomaba en prenda buena parte de su patrimonio. Las villas, lugares y castillos de Llíria, Xérica, Penàguila, Barracas alias San Pedro de Bellmont, Pina, Altura, Alcublas, Culllera y Franchavila en la Vall'Albaida, Planes, Margalida, Ibi y Torre de les Maçanes, incorporaron un importante ámbito territorial a la directa jurisdicción de la ciudad de Valencia, compensando en parte las reticencias del reino a soportar el obligatorio avituallamiento capitalino, sobre todo de granos y de ganados ${ }^{89}$. Al año siguiente el consell designaba guardas para evitar

${ }^{84}$ Cfr. Angelina Garcia, "Las crisis del siglo XIV valenciano y Bonifacio Ferrer", en Estudios de Historia de Valencia, Valencia, Universidad, 1978, pp. 85-86. La autora se limita a remitir a los registros del notario Joan de Santfeliu en el Archivo de Protocolos del Patriarca de Valencia, donde el único correspondiente a fechas próximas es el número 51 (1390-1393), el cual se encuentra foliado en fecha reciente aunque desencuadernado, habiéndose perdido algunas de sus páginas, lo que permite suponer el extravío del documento, dado que en las restantes páginas del volumen no existe referencia ninguna al pleito.

${ }^{85}$ Cfr. AMV, Manuals de consells A-19, fol. 247v (20 julio 1391).

${ }^{86}$ Cfr. AMV, Manuals de consells A-19, fol. 257-258 (19 agosto 1391). Se encargó la revisión y mejora de los estatutos vigentes para perseguir a los vagabundos y ociosos a una comisión, que habría de presentar un borrador a la próxima reunión del consell. Por otra parte, en la misma reunión el gobierno ciudadano deliberó sobre las negociaciones llevadas a término con nobles, caballeros y generosos del reino, y también con algunos prohombres, sobre el largo enfrentamiento mantenido por las inhibiciones y aemprius o derechos jurisdiccionales de la ciudad sobre el reino, pretendiendo alcanzar una solución amigable. En esta voluntaria reconciliación se alegó que del contraste de pareceres surgían disensiones y rencores, y a su vez divisiones y desolación, mientras que de la concordia nacía el amor, tal como enunciaba la doctrina evangélica.

${ }^{87}$ Se permitía mantener hasta sesenta reses por tabla carnicera y hasta ochenta si se poseían dos, cfr. AMV, Manuals de consells A-19, fol. 259 (2 septiembre 1391). El 26 de septiembre se modificaban los capítulos que regían la custodia de los cultivos de la huerta, de modo que sus guardias deberían presentar denuncias sobre invasiones y daños en los cultivos durante los cinco días posteriores a los incidentes.

${ }^{88}$ Cfr. AMV, Manuals de consells A-19, fol. 266 (13 octubre 1391).

89 En esa fecha se dan las ordenanzas para sujetar las localidades al regimiento de la ciudad, cfr. AMV, Manuals de consells A-19, fol. 271v-272 (1 diciembre 1391). Sin embargo desde el 1 de marzo de 1390 el infante Martín había comenzado a percibir parte de los quinientos mil florines de oro prometidos. 
la exportación fraudulenta de cereales vía terrestre y, a la vez, armaba algunas naves para hacer respetar las inhibiciones, además de adoptar otras medidas económicas (subvenciones y encargos) para prever el abastecimiento del almudín ${ }^{90}$. Muy pronto se desató un grave conflicto contra Xelva porque la localidad se negaba a respetar los aemprius de Valencia, lo que sería aprovechado para aplicar con toda contundencia las leyes que sostenían su hegemonía sobre el territorio del reino y, con ello, acabar para siempre con las reticencias de los estamentos respecto a sus obligaciones hacia la capital ${ }^{91}$.

Es decir, Martín lograba una sustanciosa colaboración valenciana para financiar y partir con su armada hacia Sicilia; el consell aprovechaba las circunstancias para desatar una dura represión sobre pobres, vagabundos y gente de mal vivir; los continuos rumores sobre la inminencia de un fulgurante ataque granadino mantuvieron el interés por la frontera sur, al mismo tiempo que ralentizaban los procesos contra los asaltantes de la judería ${ }^{92}$; Juan I se limitó a ordenar la ejecución de una mínima parte de los intervinientes en el asalto, sin instar otras averiguaciones, más preocupado por apaciguar los ánimos reivindicativos de una parte del patriciado y, sobre todo, de preparar su entrada en la capital del Turia, tal y como se produjo el 24 de noviembre de 1391. No hubo castigo, salvo unas pocas penas capitales sobre un puñado de desgraciados, y el asunto quedó olvidado.

Tras un breve y pacífico intermedio, el 19 febrero 1396, el consell se hacía eco de un nuevo y peligroso enfrentamiento entre Jaume Soler y Gosalbo Díeç, en el que se percibió cierta singularidad respecto a las luchas del pasado: en estos bandos se mezclaban con descaro y sin tapujos hombres de paraje, ciudadanos y menestrales, e incluso también implicaban a los propios magistrados municipales, un enfrentamiento

Los jurados entregaron 8.620 libras 8 sueldos 6 dineros a cuenta del total como pago parcial del lote territorial, cfr. APPV, Notal de Joan de Sentfeliu 51 fol. 73 (1 marzo 1390).

${ }^{90}$ Cfr. AMV, Manuals de consells A-20, fol. 8v (22 junio 1392).

${ }^{91}$ Cfr. AMV, Manuals de consells A-20, fol. 28 (28 septiembre 1392). El proceso contra Xelva fue instado por algunos carniceros de Valencia porque les habían tomado reses en prenda y vetado el uso de los pastos, cuando los derechos jurisdiccionales de Valencia lo garantizaban. Los de Xelva se negaban a aceptar que aquella zona fuese dehesa de Valencia.

${ }_{92}$ El rumor del inesperado ataque granadino, reforzado con tropas de Berbería, aumentó de forma extraordinaria inmediatamente después del asalto de la judería y del frustrado ataque a la morería. El 19 de julio los jurados se dirigían a los alcaldes y regidores de Murcia y al gobernador del reino de Valencia, dellà Xixona, transmitiéndoles noticias recién llegadas desde Chinchilla en las que se indicaba que el rey de Granada preparaba 7.000 jinetes para correr el reino de Valencia. Paradójicamente las noticias llegaban del oeste y no del sur, es decir, venían de Castilla y no de la frontera meridional con Granada, cfr. AMV Letres misives g3-5 fol. 25. En otra carta con idéntica datación se transmitía la noticia a Alzira, Orihuela, Lorca, Mula y Alcalá, ampliándose la fuente de información: el rumor había llegado a Valencia a través de Xàtiva, y allí desde Chinchilla, y a ésta desde Hellín. La misiva solicitaba información al respecto ya que en Valencia algunos sectores de la ciudad se mostraban incrédulos, cfr. Letres misives g3-5 fol. 24v. Pocos días después, el 24 de julio, los jurados se quejaban de la dilación en la instrucción de los procesos contra los asaltantes de la judería, indicando explícitamente que los rumores de inminente ataque granadino habían llegado poco después de haberse comenzado las investigaciones procesales. Sin embargo, lo más alarmante era que las morerías de las villas del reino habían comenzado a armarse y a avituallarse, un peligro en ciernes que se relacionaba bien con el deseo de protección ante los riesgos de asaltos de cristianos bien por la posibilidad de convertirse en quinta columna del ejército granadino, cfr. AMV, Manuals de consells A-19, fol. 248v-249v (24 julio 1391). 
en efervescente crecimiento que se prorrogaría sin intermitencias hasta la guerra civil del Interregno ${ }^{93}$. Ese conflicto se había gestado por la abierta enemistad entre dos grupos, presentes en la corte real y en la ciudad, arrastrando a las villas del reino y a los mismos menestrales de la capital en sus reivindicaciones que, plenamente expresadas durante el trienio 1389-1391, engendraron las bases de un gravísimo enfrentamiento colectivo que se había cebado sobre la judería. Dada la peligrosidad inherente a esas violencias el consell intentó poner en vigor, otra vez, el privilegio de los cien hombres a caballo pero un estatuto juramentado y desconocido, así como la pretextada falta de liquidez en las arcas municipales obligó a desestimar aquella medida ${ }^{94}$. En cualquier caso, fue durante ese trienio negro cuando se forjó una fuerte bipolarización en el seno de la sociedad política de la ciudad y del reino, pronta a estallar de forma violenta en la coyuntura propicia, cuando se produjo la sucesión en el trono del difunto Juan I. Entonces la tradicional válvula de escape de la presión política y social estaba completamente inutilizada.

\section{CONCLUSIÓN}

En 1391, un importante grupo patricio había apoyado el crecimiento de la judería, mientras otro se mostraba contrariado por ello. Razones ideológicas, religiosas, políticas y posiblemente económicas y financieras -vinculadas a los arrendamientos y recaudaciones fiscales y de la hacienda local y regnícola- opuso a los dos grupos que ya rivalizaban por la hegemonía en la ciudad, en el reino y en la corte real, provocando una explosión de violencia contra los judíos al calor del negativo impacto de las obras de ampliación del barrio. Tras el apaciguamiento de la ciudad y un breve período de calma, en 1396, volverían a aflorar aquellas rivalidades, convirtiendo a Valencia durante el reinado de Martín el Humano (1396-1410) y los años posteriores a su muerte (1410-1412) en un campo de batalla entre dos grupos irreconciliables.

93 Salvador Carreres Zacarés, Notes per a la història dels bandos de València, Valencia, Imprenta Fill de F. Vives Mora, 1930, vol. 2, doc. X, pp. 40-41 (19 febrero 1396). El 21 de marzo Goçalvo Dieç desafió y declaró enemigos a algunos ciudadanos que ejercían o habían ejercido cargos de gobierno, acusándoles de parcialidad y de actuar a favor de Jaume de Soler y de su bando. El consell ratificaba que en esos enfrentamientos quedaban comprendidos grandes personajes de la ciudad, que terminarían acaudillados por dos linajes enemigos: Vilaragut y Centelles, cfr. doc. X, pp. 41-42 (21 marzo 1396).

${ }^{94}$ AMV, Manuals de consells A-19 fol. 283-283v (19 febrero 1396). Mientras una parte del consell se mostró de acuerdo en reorganizar la milicia, otro grupo argumentó que no se podía o no se debía volver a ponerla en vigor por dos razones: ateniéndose a un estatuto juramentado por el consell en tal sentido y por no aumentar los gastos de la hacienda municipal. No obstante, se pidió a los abogados de la ciudad que estudiaran la posibilidad de revocar aquella disposición, dada la situación de extraordinaria violencia que se padecía. En cualquier caso la milicia nunca volvió a ponerse en vigor con cien titulares subvencionados. 